\title{
Covering the dead in later prehistoric Britain: elusive objects and powerful technologies of funerary performance
}

\section{Article}

Published Version

Creative Commons: Attribution 4.0 (CC-BY)

Open Access

Cooper, A., Garrow, D., Gibson, C. and Giles, M. (2019) Covering the dead in later prehistoric Britain: elusive objects and powerful technologies of funerary performance.

Proceedings of the Prehistoric Society, 85. pp. 223-250. ISSN 0079-797X doi: https://doi.org/10.1017/ppr.2019.8 Available at https://centaur.reading.ac.uk/84218/

It is advisable to refer to the publisher's version if you intend to cite from the work. See Guidance on citing.

To link to this article DOI: http://dx.doi.org/10.1017/ppr.2019.8

Publisher: Cambridge University Press

All outputs in CentAUR are protected by Intellectual Property Rights law, including copyright law. Copyright and IPR is retained by the creators or other copyright holders. Terms and conditions for use of this material are defined in the End User Agreement.

www.reading.ac.uk/centaur

\section{CentAUR}


Central Archive at the University of Reading

Reading's research outputs online 
Proceedings of the Prehistoric Society 85, 2019, pp. 223-250 (C) The Prehistoric Society. This is an Open Access article, distributed under the terms of the Creative Commons Attribution licence (http://creativecommons.org/ licenses/by/4.0/), which permits unrestricted re-use, distribution, and reproduction in any medium, provided the original work is properly cited.

doi:10.1017/ppr.2019.8 First published online 30 August 2019

\title{
Covering the Dead in Later Prehistoric Britain: Elusive Objects and Powerful Technologies of Funerary Performance
}

\author{
By ANWEN COOPER ${ }^{1}$, DUNCAN GARROW ${ }^{2}$, CATRIONA GIBSON ${ }^{2}$ and MELANIE GILES ${ }^{1}$
}

This paper examines the containment and covering of people and objects in burials throughout later prehistory in Britain. Recent analyses of grave assemblages with exceptionally well-preserved organic remains have revealed some of the particular roles played by covers in funerary contexts. Beyond these spectacular examples, however, the objects involved in covering and containing have largely been overlooked. Many of the 'motley crew' of pots and stones used to wrap, cover, and contain bodies (and objects) were discarded or destroyed by antiquarian investigators in their quest for more immediately dazzling items. Organic containers and covers bags, coffins, shrouds, blankets - are rarely preserved. Our study brings together the diverse and often elusive objects that played a part in covering and containing prehistoric burials, including items that directly enclosed bodies and objects, and those that potentially pinned together (now mostly absent) organic wraps. Overall, we contend, wrapping, covering, and containing were significantly more prevalent in prehistoric funerary practices than has previously been recognised.

Keywords: Grave goods, later prehistoric Britain, burial, funerary performance, covering, containment, revelation, transformation, coffins

In 2013, the artist Rob Heard embarked on an emotionally powerful project, Shrouds of the Somme, to create 19,240 shrouded figures - one to represent each of the British servicemen who died on the first day of the Battle of the Somme, 1st July 1916 (Fig. 1). Working his way down a list of the names of missing soldiers, Heard hand-crafted each 12-inch $(c .30 \mathrm{~cm})$ figure, cutting and stitching the calico shrouds and covering and binding the bodies in what he described as a 'ritual of creation, remembrance and personal introspection' (Heard 2018). Clearly one of Heard's

\footnotetext{
${ }^{1}$ Department of Archaeology, School of Arts, Languages and Cultures, University of Manchester, Oxford Road, Manchester, M13 9PL Email: anwen.cooper@manchester. ac.uk

${ }^{2}$ Department of Archaeology, School of Archaeology, Geography and Environmental Science, University of Reading, Whiteknights, PO Box 217, Reading, Berkshire, RG6 6AH
}

main aims was to materialise the almost unimaginable enormity of the collective loss of life. Of particular interest in the context of this article is how Heard captured both the anonymity and personality of death through his use of shrouded figures. On the one hand, the shrouds create a sense of sameness - the power of the artwork is, in part, generated by the mass of seemingly identical, bound figures arranged in neat lines. On the other hand, the act of shrouding each figure, together with Heard's access to individual names, allowed him to engage physically and emotionally with each person that died. Beyond the immediate and humbling message of his artwork, Heard was able to elicit how objects and processes that immediately frame dead bodies are powerful representations in their own right, and can play a central role in coming to terms with death.

Our own interest in covering the dead came about through a collaborative project between the Universities of Reading and Manchester and the British Museum to 


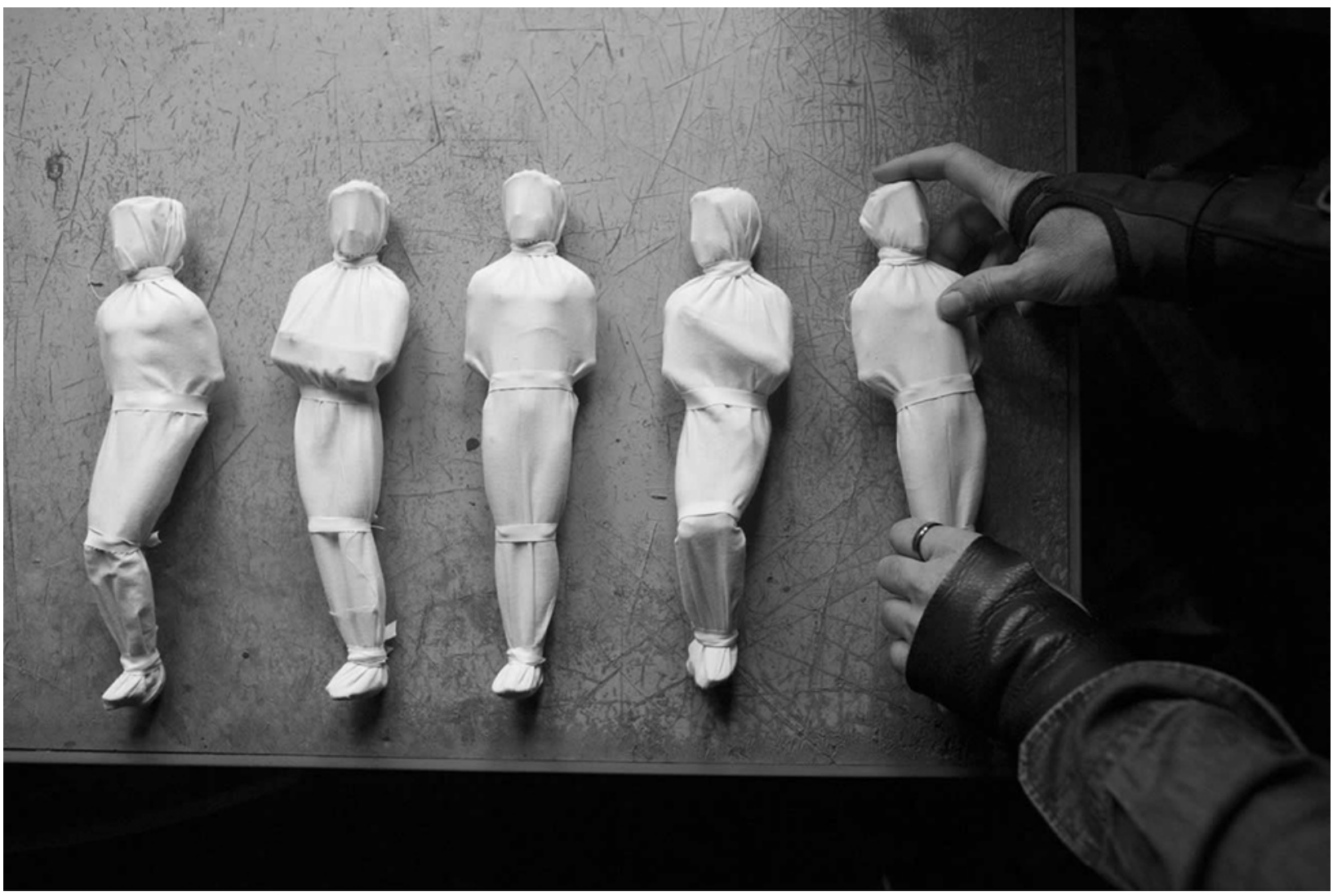

Fig. 1.

Five of the 19,240 figures from Shrouds of the Somme by artist Rob Heard (https://www.shroudsofthesomme.com/)

investigate prehistoric grave goods. In brief, the 'Grave Goods' project is investigating objects found in graves from c. $4000 \mathrm{BC}$ to $\mathrm{AD} 43$ within six case study areas across Britain: Orkney/Outer Hebrides, Gwynedd/ Anglesey, Cornwall, Dorset, Kent, and East Yorkshire (Fig. 2). One key aim of the project - and the main reason for focusing in detail on six case study regions - is to consider the whole spectrum of objects and materials that were caught up in prehistoric funerary processes, rather than to focus primarily on more immediately alluring assemblages as has been the case in many previous studies (eg, Woodward \& Hunter 2015; see https://blogs.reading.ac.uk/grave-goods/ for more information on the project). In gathering a database of nearly 6000 objects - all of those in formal burials within our study areas (see Appendices 1, S.3 \& S.4 for methodology) - it became clear that items directly associated with covering the prehistoric dead those involved in binding, enclosing, capping, and pinning together human remains and the objects buried with them - form a significant component of grave assemblages and vary hugely in their makeup. They range from woven grass baskets and 'blankets' of quartz, to pots with quernstone lids and fastenings used to hold organic bundles together. It was also evident that although 'covering objects' (as we might describe them) are discussed widely as an element of materially rich prehistoric burials from elsewhere in Europe and beyond (eg, papers in Harris \& Douny 2014; Riggs 2014), those from prehistoric Britain have thus far evaded thorough analytical attention.

Recent scientific studies of evidence from exceptionally well-preserved grave assemblages (eg, Melton et al. 2013; Harris 2014; 2015; Lelong 2014; Jones 2015) have brought into focus not only the amazing organic objects sometimes involved in covering prehistoric bodies and objects in Britain but also the significant role these items potentially played in burial performances. In this paper, we seek specifically to uncover the full range of objects involved in covering bodies and objects in 


\section{A. Cooper et al. COVERING THE DEAD IN LATER PREHISTORIC BRITAIN}

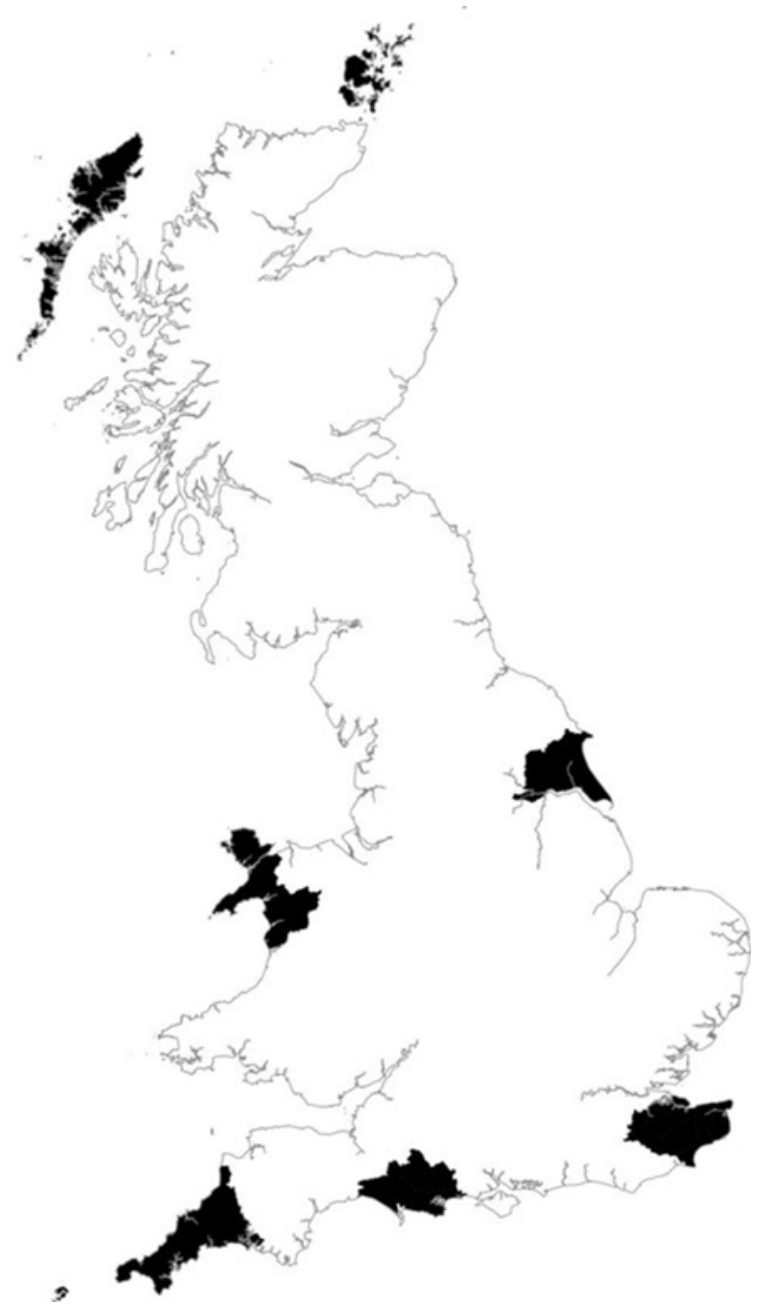

Fig. 2.

Grave Goods project case study areas

British funerary practices from c. 4000 BC-AD 43. Whilst the main empirical weight of our paper is focused within the six case study regions, we draw on wider examples where relevant. In addition to exposing fully the diverse objects involved in covering, we will bring to light three specific sets of evidence that have never previously been analysed in detail. In doing so, we provide vital empirical support for previous suggestions as to the significance of wrapping bodies and objects in prehistoric funerals (eg, Brück 2004; 2019, 78-9; Harding \& Healy 2007, 243; A.M. Jones 2010; A. Jones 2015,241$)$. We aim to emphasise the diversity of materials and objects that were employed in covering, well beyond the exquisite perishable items from remarkable burials that have previously attracted attention. By asking what this array of objects was doing in graves (capping, confining, pinning, and so on), rather than focusing on what they are or were prior to burial (eg, a brooch, an awl, a chainmail shirt), we also hope to shed new light on understandings of grave goods at a much broader level.

THE 'MISSING MAJORITY': ORGANIC COVERINGS FROM MATERIALLY-RICH GRAVES IN PREHISTORIC BRITAIN

Organic covers and containers have long been recognised as an aspect of prehistoric grave assemblages in Britain. Despite the sometimes hasty or uncontrolled manner of their work, antiquarian excavators frequently recovered and described traces of baskets, coffins, biers, leather bags, and so on (eg, Warne 1866; Greenwell 1877; Mortimer 1905). Further instances of organic covers and containers are logged in excavation reports throughout the 20th century (see Stead 1991; Lelong 2014, 120; Jones 2015, table 21.2). The ideas that wrapping and layering in burials are more widespread than has previously been recognised and that covers and containers constitute an interesting aspect of burial processes in their own right have come to the fore more recently (eg, Brück 2004; 2019; Gilchrist \& Sloane 2005; Harding \& Healy 2007; Melton et al. 2010; 2013; 2016; Giles 2012). Overall, archaeologists are now much better equipped to deal with the often fragile and fragmentary traces of organic covers, linings, and containers (Harris \& Douny 2014, 20). Through their detailed engagement with these objects, researchers have also come to appreciate more fully the spectrum of materials involved, the considerable time and effort invested in making these items, and the active roles that enclosing and layering played, particularly in funerary contexts.

In order to introduce some important characteristics of the material to be discussed, it is worth detailing briefly the evidence from one particular, wellpreserved context. The stone cist burial at Langwell Farm, Strath Oykel in the Scottish Highlands (Lelong 2014) was initially uncovered and recorded by landowner, Jonathan Hampton, and digger driver, John White, during peat clearance. Subsequent excavations by GUARD Archaeology revealed the tightly flexed skeleton of a young woman. She was wrapped in a brown cattle hide, the long edges of which met at her back 'so that it enclosed her like an envelope' (Lelong 2014, 116). Four small stones held the hide 
in place. A hazel wand, still enclosed in its bark, was at her knees. Woven basket-like material, observed around the head and lower legs, did not survive for detailed analysis. However, using photographic evidence, Harris (in Lelong 2014, 94-6) was able to pick out the 'open twining' structure of the weave, suggesting that this fabric could have either covered the burial entirely, or comprised a cap upon the woman's head and a simple coverlet over her lower legs (Fig. 3). Disrupting any temptation to picture a revered corpse cosily bedded in a skin that was clean, sleek, and long-treasured, Lelong points out that 13 mites recovered from the cow fur suggest that the hide was not processed prior to burial. The beast may have been slaughtered specifically for the funeral; the wrap itself could have been 'warm, raw, and bloody' (Lelong 2014, 123).

More broadly, captivating insight into the significance of covering and containing in Early Bronze Age (EBA) funerary processes is given by, for instance, the thick wads of charred textile and burnt bone pin, probably remnants from the cremation of a heavily bound body over a centrally positioned pit pyre, at Over Barrow 2, Cambridgeshire (Harris 2015; Evans et al. 2016), and the folded bear skin, secured with a copper-alloy pin, that enclosed the cremated remains within the stone cist at Whitehorse Hill, Dartmoor (Jones 2015). This last burial was accompanied by, amongst other things, an intricate basket of lime bast containing a unique set of multi-material items. Arresting covers and containers from Middle Iron Age (MIA) interments include the chainmail 'tunic' laid over the corpse at Kirkburn (K5), East Yorkshire (Stead 1991), further contained by the chariot box itself (Fig. 4).

Recent synthetic accounts of wrapping and layering in British prehistoric burials have focused almost exclusively on evidence from the EBA and MIA, and, in particular, on certain more alluring types of cover: preserved textiles, animal hides, and log coffins. A significant array of materials was employed for such purposes. Cloth, matting, and baskets were fashioned from nettle, flax, sheep wool, grass, lime bast, and cattle hair. Hides of cattle, sheep, stoat, fox, pine martin, and bear and coffins, biers, and timber coverings of oak, alder, elm, and birch have been identified. The fastenings that secured covers in place are typically discussed in less detail (although see Sheridan et al. in Jones 2015, 69-71), but were mainly of bone, copper alloy, iron, or stone. As well as the effort of gathering these materials, considerable energy and skill were invested in making organic covers and wraps, in the processing of hides, the seasoning of wood, splitting of timbers, and crafting of coffins and biers, and the weaving, stitching, and possibly even embroidery of fabrics (see Giles 2012, 130; Lelong 2014, 93-7; Cameron \& Mould in Jones 2015, 64-8; Cartwright et al. in Jones 2015, 72-4).

Overall, this evidence exposes the extraordinary richness of what Hurcombe $(2014,1)$ has described as the 'missing majority' - perishable material culture - in British prehistoric funerary contexts. Given the common incidence of multiple forms of layering and enclosure within a single grave - for instance the layers of matted plant material both underlying and covering the main grave assemblage, together with the bear skin wrapping the cremated remains and the basket of objects at Whitehorse Hill, Dartmoor - it is clear that covering sometimes played a central role in burial performance (Jones 2015, 241; see Banck-Burgess 2014; Harris 2014 for wider examples). Covering and containment also took place at various points in funerary processes: before cremating the body at Over Barrow 2 (Harris 2015), during the arrangement of the grave Langwell Farm (Lelong 2014), or at multiple stages (as above).

\section{WHY COVER? INTERPRETATIONS OF COVERING IN PREHISTORIC BURIALS AND BEYOND}

Detailed reflections on the role of covering have taken place both in relation to the evidence outlined above (see in particular Giles 2012; Parker Pearson et al. 2013; Lelong 2014; Jones 2015) and much more widely (see Gilchrist \& Sloane 2005; papers in Harris \& Douny 2014; Riggs 2014 for key recent archaeological and anthropological accounts; Gell 1993; Hendry 1993 for broader social analyses of wrapping practices). Despite the diverse origins of these discussions, similar (and somewhat overlapping) broad themes have arguably emerged (Table 1). In brief, previous accounts have emphasised the potential transformative, performative, protective, organisational, and metaphorical capacities of covers. Covers can play a central role in expressing and shaping the identities of the deceased and of mourners. They are also important practically - covers can hold decaying bodies together, stem any associated leakage, and provide a means of moving the dead. In this sense, they can offer insight into attitudes towards the integrity of the body, the stability and fluidity of 


\section{A. Cooper et al. COVERING THE DEAD IN LATER PREHISTORIC BRITAIN}

(a)
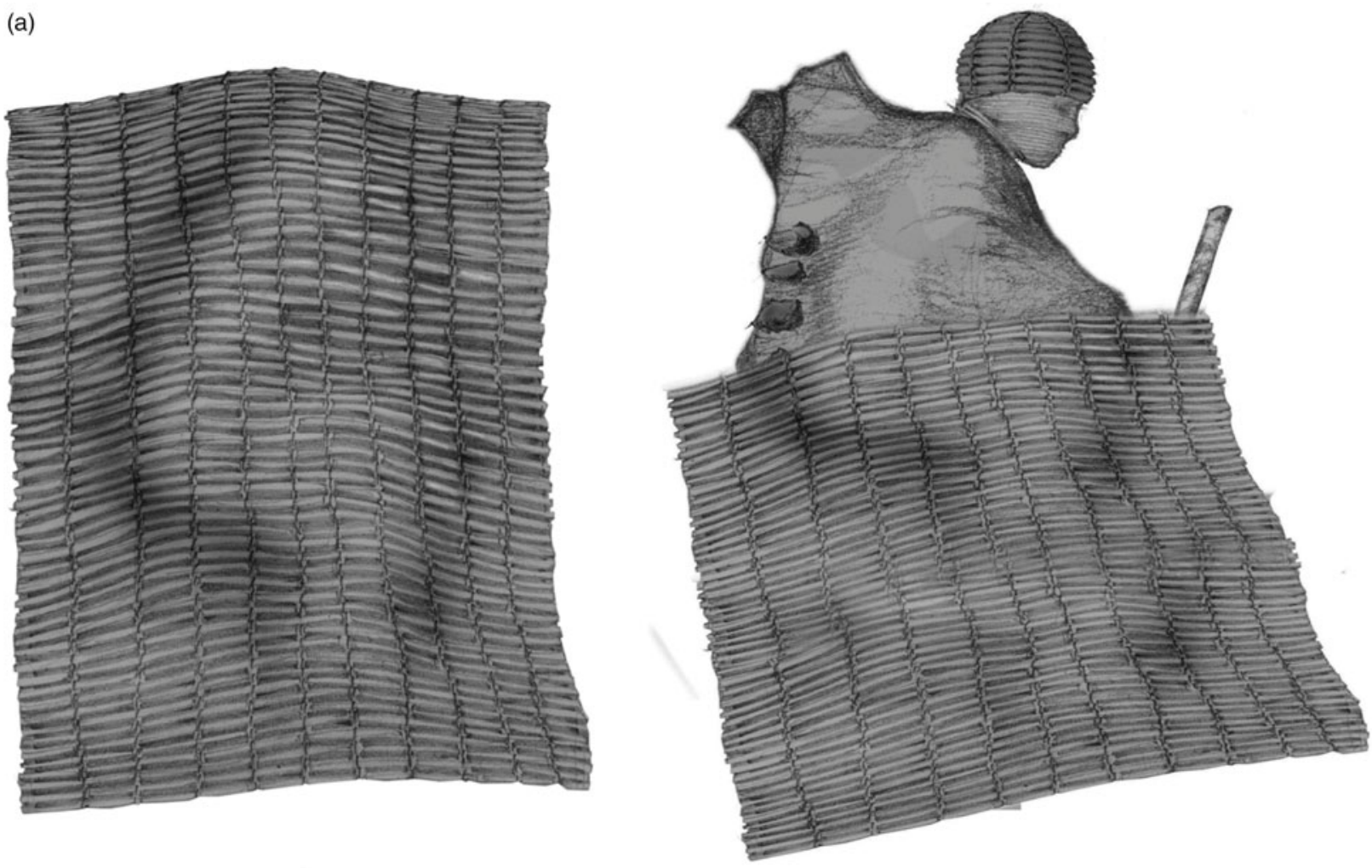

(b)

(c)
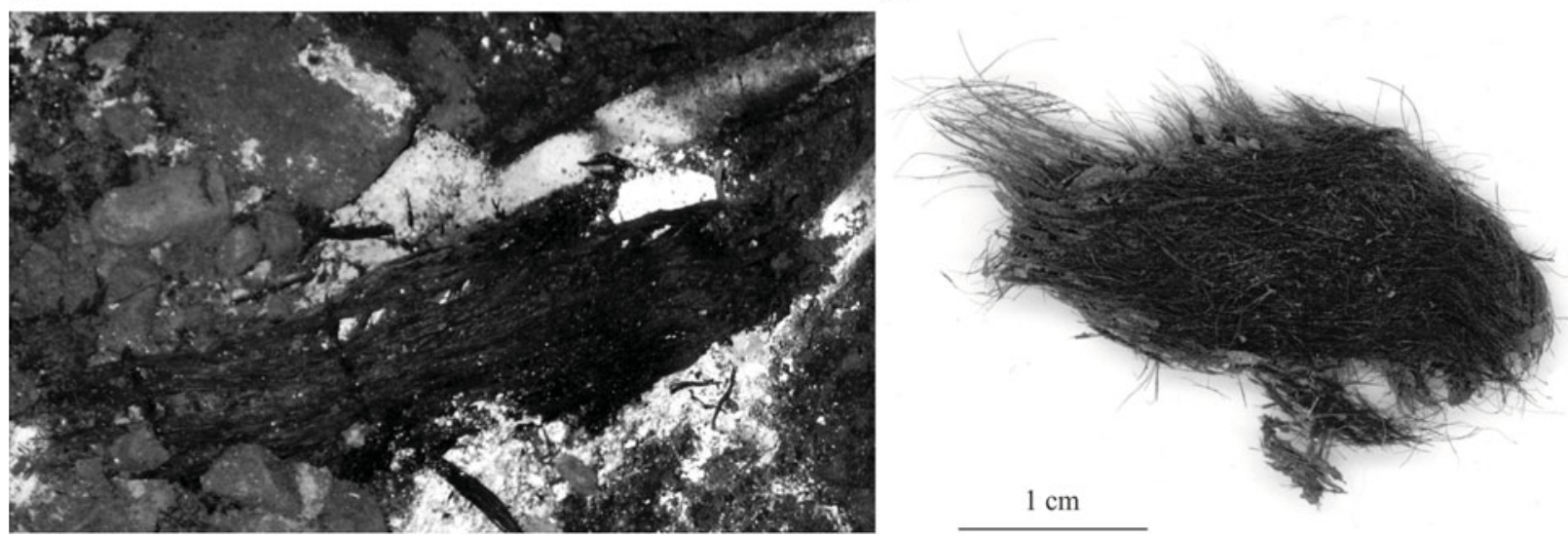

Fig. 3.

Early Bronze Age cist burial from Langwell Farm, Strath Oykel (Lelong 2009; 2014, figs 2, 17 \& 29; reproduced courtesy of York Archaeological Trust): a. reconstruction of the burial showing two different interpretations of the evidence (@ David Hogg); b. woven material in the leg area; c. well-preserved cattle hide (hair roots to the top left)

bodily substances, and the mobility of human remains following death.

Central to their interpretation as mediums for materialising social identities in British prehistoric burials has been the idea that covers 'add value' to their contents (eg, Hendry 1993, 6). Particularly in the EBA, covering is typically viewed as an attribute of high or special status burials. Melton and colleagues see the care invested in wrapping 'Gristhorpe Man', East Yorkshire in his cattle hide and oak coffin with 
THE PREHISTORIC SOCIETY
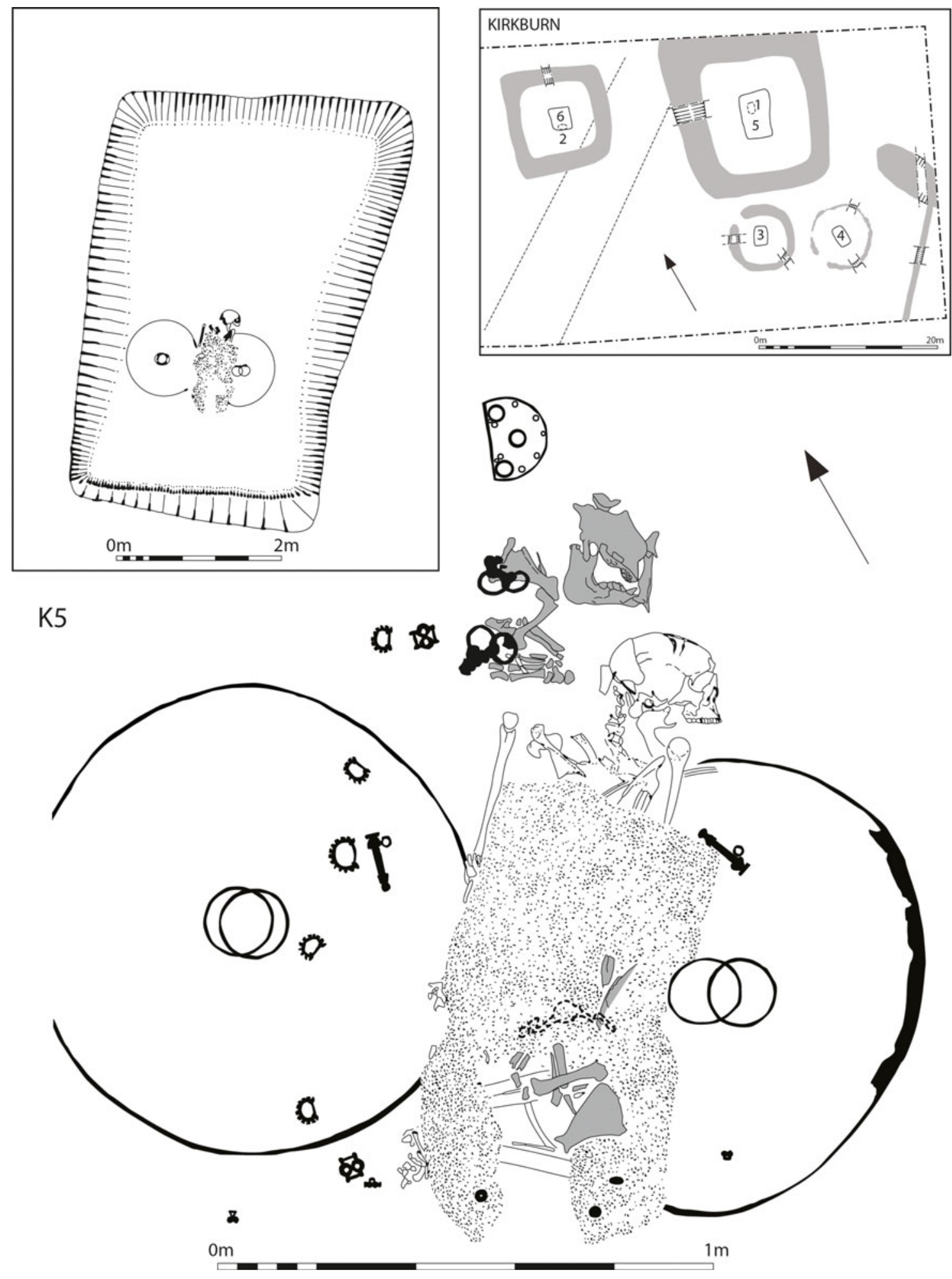

Fig. 4.

Containment - corpse, chainmail cover, and chariot box, with the D-shaped box placed by the individual's head, burial K5 at Kirkburn, East Yorkshire (Giles 2012, fig. 5.16) 


Broad interpretation
The active and transformative qualities of covering and
containing. Covers can conceal, reveal, camouflage,
indicate, conserve, unify, separate, elevate, and
re-present their contents
The performative and potentially dramatic effects of
covering and revelation. Covering helps to create a
sense of occasion. Covers can emphasise the value of
their contents or, conversely, create equivalence between
things which might otherwise be differentiated. It
enables the creation of layers of knowledge, including
secret knowledge, and can form a basis for expressing
command over that knowledge. The possibility of
revealing what is covered or puncturing a cover (and
thus releasing potentially dangerous contents) heightens
the sense of drama associated with covering

The protective capacities of covers. Covers protect the dead, both practically (in terms of inhibiting decay) and metaphorically (they can represent a form of embrace, a shield against dangerous forces and so on)

Covering holds things together (bodies, sets of objects, etc), stems leakage of potentially polluting things (eg, liquids from putrefying bodies) and, at a practical level, can help to make the dead (and other objects) more mobile

Covers and containers can act as organisational devices they help to order things, both physically and metaphorically. They can group objects or body parts in a grave and/or, in time, mark out separate aspects of funerary processes and also operate as a form of closure - finishing things off. This is useful for archaeologists in trying to unpick burial processes. They can also mark out social boundaries - differences between the self/other, individual/society, people/the supernatural world and so on, acting as a medium for expressing and shaping idealised social orders

The metaphorical potential of the idea of covering. Metaphors of nakedness and dress have been seen as fundamental to human concerns in the lead up to death. Pots can be viewed as clothing for the dead, the covering and containment of dead bodies resonates with the covering and containment of the unborn body in the womb, covers are sometimes removed from the grave and come to operate as the dead person

The role of covers in expressing and shaping social identities. It might express or reconfigure the taste of the coverer, the character of the thing which is covered, or relationship(s) between the coverer(s) (mourners) and the covered (the dead). In connection with this point the physical manifestation of the cover itself (material makeup, processes of making, physical properties such as permeability, etc) can be extremely important
Hendry 1993, chap. 1; Brück 2004, 319; Gilchrist \& Sloane 2005; Jones 2010; Melton et al. 2010, 111; Giles 2012; Parker Pearson et al. 2013, 45-7; Banck-Burgess 2014; Lelong 2014, 121; Jones 2015; Proctor et al. 2016

Gell 1993; Brück 2004, 319; Gilchrist \& Sloane 2005, 110; Giles 2012, 122; Croucher \& Richards 2014, 214-5; Markovicky 2014, 10

Gilchrist \& Sloane 2005, 111; Giles 2012, 131

Gell 1993; Hendry 1993, 4; Gilchrist \& Sloane 2005, 92, 159; Banck-Burgess 2014, 154; Harris 2014, 116-8, 129; Riggs 2014, 23; Jones 2015, 233; Woodward \& Hunter 2015, 515; Brown Vega 2016, 226

Hendry 1993; Utriainen 2004, 134-5; Gilchrist \& Sloane 2005, 27; Gleba 2014, 141; Harris \& Douny 2014

Weiner 1992, 153-4; Gell 1993, 3; Hendry 1993, 13; Brück 2004, 318-9; Gilchrist \& Sloane 2005, 23-7; Giles 2012, 122; Douny 2014; Lelong 2014, 121; Markovicky 2014; Jones 2015, 240; Brown Vega 2016 
a debarked carved human face as confirmation in itself of the dead man's 'high status' (Melton et al. 2010, 111). The carving of some log coffins into boat-shapes is argued either to represent elite mobility and control of access to goods or belief in supernatural fluvial travel to the underworld (Parker Pearson et al. 2013, 45-7). Jones $(2015,228)$ notes that burial in furs may have 'empowered' the deceased, imbuing them with the status and magical symbolism of the animal from which they were derived. The extravagance of burning and depositing a potentially highly valued textile shroud in the grave at Whitehorse Hill is seen as evidence of the status of the person buried or the family who consigned the fabric to the flames (Jones 2015, 233). Lelong (2014, 121), unusually, highlights the rather 'ordinary' character of materials and objects assembled within the grave at Langwell Farm. Even so, she ultimately interprets these items as the possessions of a spiritual leader or shaman. Interesting here is the contrast between understandings of shrouds and coffins as an emblem of prestige in prehistoric burials and understandings of similar items in more recent burials (eg, Gilchrist \& Sloane 2005), where they are typically viewed as mechanisms for creating equivalence between people - an attribute used to great effect by Heard in Shrouds of the Somme.

Existing discussions about covering and containment in prehistoric burials (and more broadly) form a useful platform for the analysis that follows. At one level, covering practices have been thought through in detail and are in certain respects wellunderstood. At another level, however - particularly once burial assemblages are considered holistically, rather than in relation to particular materials or object categories or spectacular discoveries - it is clear that existing considerations of covering and containing have been constructed on a partial basis. These accounts have addressed only a fraction of the diversity of objects and materials potentially involved. Some studies have innovatively embraced Gell's $(1993,38)$ abstract conceptualisation of tattooing as 'wrapping in images', and taken into consideration other unusual examples of covering, including the layering of soils in burial monuments (Brück 2004, 321; 2019, 225; Harris 2014, 125). At the same time, a range of other traces of covering - pots with stone, skin, clay, or wooden lids, timber and other organic grave linings (as opposed to $\log$ coffins), flint and chalk 'blankets', fasteners for shrouds and bagged cremation burials - have been
TABLE 2. OBJECTS INVOLVED IN COVERING AND CONTAINMENT IN PREHISTORIC BURIALS

\begin{tabular}{|c|c|}
\hline Role in burial & Object \\
\hline $\begin{array}{l}\text { Containing human } \\
\text { remains only }\end{array}$ & Tankard \\
\hline $\begin{array}{l}\text { Containing human } \\
\text { remains/objects }\end{array}$ & $\begin{array}{l}\text { Bag, basket, box, bucket, chariot/ } \\
\text { cart, coffin, helmet, other vessel } \\
\text { (eg, steatite urn), pot, shroud, } \\
\text { other wrap (eg, textile), grave } \\
\text { lining }\end{array}$ \\
\hline $\begin{array}{l}\text { Containing objects } \\
\text { only }\end{array}$ & Cup, strainer \\
\hline Covering companion & $\begin{array}{l}\text { Awl, bead(s), brooch, button, } \\
\text { collar, dagger, knife, needle, } \\
\text { pendant, pin, point, staple, strap } \\
\text { union/fitting, toggle, tusk/tooth, } \\
\text { wire }\end{array}$ \\
\hline $\begin{array}{l}\text { Covering human } \\
\text { remains only }\end{array}$ & Shield \\
\hline $\begin{array}{l}\text { Covering human } \\
\text { remains/objects }\end{array}$ & $\begin{array}{l}\text { Assemblage, chariot/cart, other } \\
\text { cover (eg, hide), lid, pot }\end{array}$ \\
\hline
\end{tabular}

'Assemblage' is used to describe assemblages of objects (eg, shells, quartz pebbles, flint nodules, pottery sherds) used to cover the burial assemblage or base of the grave

overlooked to a significant extent. Overall, therefore, in our investigation of British prehistoric burials, we hope to demonstrate that it is these materials and items beyond rare discoveries of organic wraps and containers that constitute the 'missing majority' of covers and containers, rather than the perishable items themselves. DIVERSE, UNDERSTATED, AND OFTEN OVERLOOKED:
COVERS AND CONTAINERS IN PREHISTORIC GRAVES

All of the object types within the Grave Goods database that were potentially involved in covering and containing bodies and objects in prehistoric burials are listed in Table 2. This includes objects that were used directly for covering or containing human remains and/or other grave goods, and items that we will call 'covering companions' - formal fasteners such as pins and brooches (usually interpreted as dress items), and other bits and pieces (staples, bits of wire, beads, and so on) that were either used directly to secure organic covers and containers or which formed part of fastening devices (eg, beads strung onto a drawstring).

It must be stressed that, for various reasons, this dataset of covers and containers is difficult to define. This is partly because of the fragmentary character 


\section{A. Cooper et al. COVERING THE DEAD IN LATER PREHISTORIC BRITAIN}

and poor preservation of organic wraps and containers (mentioned above). Additionally, ambiguity is arguably central to the character and perhaps past meanings of covers and containers in burials. Some of the object categories listed above are inherently fluid in purpose (eg, wire); others sit at the borders of what we might define as objects and what we might define as architecture (eg, timber grave linings); others still had a completely different role prior to their involvement in the funerary process (eg, daggers, brooches, chariot boxes). Thus it is important to state clearly where and why we have drawn lines in this respect.

Unlike Hendry (1993), we have not included clothing as a form of covering unless the item concerned was clearly used primarily as a cover or container in the burial context; for instance the helmet used to contain the Late Iron Age (LIA) cremated remains at Bridge, Kent (Farley et al. 2014). While we accept that garments can operate as a form of cover, we are interested here specifically in objects that were used directly to conceal bodies and objects for burial rather than those that were more overtly part of burial costumes - a subtle but important distinction. Similarly, although we will touch upon objects that were used to line graves or to support the burial itself - scatters of pottery, shells, quartz, and matting on the base of the grave, or formal timber grave structures - many of these items did not strictly speaking cover or contain burial assemblages. Stone cists and timber grave linings did, at one level, enclose prehistoric burials. However these structures arguably also operated as stand-alone grave architecture in their own right. More importantly, formal grave linings are relatively immobile; they may well have been put in place entirely separately to the processes of preparing the body and assembling portable objects to deposit in the grave that we are mainly interested in here (see also Gilchrist \& Sloane 2005).

Even considering only the objects that directly covered or contained human remains (pots, coffins, baskets, shrouds, etc), these represent $29 \%$ of all objects recorded in the Grave Goods database. If we add to this group grave liners, covering companions, and objects that immediately covered and contained other grave goods, it is clear, firstly, that covering objects comprise a very substantial component of prehistoric grave assemblages, and secondly that, rather than being a feature primarily of 'high status' burials, covering and containment were, without doubt, fundamental elements of prehistoric funerary processes more broadly. In summarising this evidence, it is worth highlighting that traces of covering and containment were logged only rarely in Neolithic burials (only ten objects from eight graves were identified). The range of objects involved in covering and containment was most diverse in the EBA and M/LIA. Additionally, in at least one third of graves where there was clear evidence for covering and containment, more than one object was involved. In most cases these groupings comprise what we might describe as composite or partner objects - a pot and a lid, or an organic bag and a pin to fasten it. Elsewhere, however, as at Whitehorse Hill (described above), covering and containment were seemingly central to the burial performance. For instance in Grave 4298 on the A2 Pepperhill to Cobham road scheme excavations (Allen et al. 2012, fig. 3.85), the LIA cremation burial (contained within a wooden box) was accompanied by four pots, which held, respectively, an organic bag tied with a copper-alloy strip, pig bones, sheep/goat and cow bones, and a possible copperalloy knife.

Overall, this material offers significant scope for further investigation. In the remainder of this paper, we will focus on just three specific, and thus far underexposed, aspects of covering practices in prehistoric burials in Britain: organic containers and related items (coffins, biers, plank covers, etc) covering companions which can, with care, provide indirect evidence for covering (pins, brooches, staples, etc); and the diverse but also understated and almost entirely overlooked evidence for capping (blankets, lids, upturned pots, etc). Since ceramic vessels have long been recognised as funerary 'urns', this class of container is not discussed in detail within this paper; it will however, be given more in-depth treatment in the project's final monograph.

\section{COFFINS: CARRYING AND CONTAINING THE DEAD}

The coffin sits in an ambiguous position as a grave good, sometimes interpreted as an important and prestigious element of grave furniture, at other times dismissed more as an accessory to the burial, merely a container. A total of 374 definite and probable coffins have been recorded within our case study areas: 45 are Beaker/EBA, 293 are MIA. Only a single coffin was Neolithic whilst three were LIA; 32 could not be closely dated. In the Neolithic, this is perhaps unsurprising as burial was generally of a more 
collective nature in long barrows and chambered tombs, which themselves could be seen as 'containers'. In the Middle Bronze Age (MBA) to Early Iron Age (EIA), the rise of cremation as the predominant funerary practice may partly account for the lack of coffins, as bodies were more often placed in ceramic rather than wooden receptacles. MIA coffins - the vast majority of them from East Yorkshire - have received far less attention than their EBA equivalents. They appear to have been a common element of burial at that time in that region and involved more formal carpentry construction methods. At the most elaborate end of this tradition of 'boxed' burial was, of course, the chariot itself (Giles 2012, 131). EBA coffins are generally better preserved than those of Iron Age date, mainly as a consequence of differential preservation conditions (EBA coffins were often placed in deep graves and covered with soil and turf mounds which helped promote damp conditions). As a result, EBA coffins form the main focus of our discussion here.

Certain forms of EBA coffins have been reviewed in detail recently (eg, Melton et al. 2010; Noble \& Brophy 2011; Melton et al. 2013; Parker Pearson et al. 2013, appx 4.1; Jones et al. 2017; 2019); it is not necessary for us to dwell in detail on these here. In short, this work has considered almost exclusively tree-trunk coffins and has produced a relatively restricted range of interpretations, focusing primarily on the association of these coffins with 'high status' (mostly male) burials, and on the symbolism of being interred in a tree or 'boat'. Augmenting and giving empirical detail to the observation by Parker Pearson et al. $(2013,44)$ that 'the tree-trunk coffin was just one form of wooden container or support that was used during the EBA', it should be noted that a wide variety of other, coffin-related objects were found in EBA (also in Neolithic and LIA) burials within our case study areas, including plank lids, grave liners, biers, box/caskets, and wicker baskets (Fig. 5). Prehistoric timber burial containers should therefore be seen as a continuum of objects comprising different materials, manifestations, degrees of completeness (some of these objects only partially framed or supported the body), and positioning relative to human bodies and objects. As well as bringing out the full variety of coffin burials, in this section we focus on three specific aspects of these burials that are of significant interest but which have not previously been discussed in detail: the state (articulated or otherwise) of the body and number of individuals contained within coffins; the deposition of cremation burials within coffins; and the significant signs of charring or burning seen on some coffins.

\section{Disarticulated and multiple burials in coffins}

Sometimes bodies contained within coffins were only partial, or had been seemingly been put back together from a disarticulated state (Fig. 6). At Canada Farm, Dorset, the primary male Beaker burial had been partly defleshed and possibly excarnated; neither the jaw nor the arms were in the correct anatomical position (Bailey et al. 2013, 23). As this adult male had a blunt force injury to his head that had not fully healed, he may have died away from home and been carried back in a semi-decomposed state. This coffin therefore perhaps performed as both container for the decomposing body and protective barrier for those charged with bringing an increasingly noxious set of remains home. At Ingleby, Yorkshire, the adult female on a bier had also seemingly been excarnated; only her torso and head remained (Manby et al. 2003, 62). It is not always possible to distinguish whether bodies were partly disarticulated at the moment of burial or were subsequently revisited or disturbed. For example, the adult male burial of Cowlam Barrow 59, East Yorkshire, was in a crouched but not anatomically correct position: the sacrum was replaced by the scapula and the lower vertebrae were missing (Greenwell 1877, 226). Similarly, two coffined burials at Fordington Farm, Dorset, both contained disarticulated and carefully arranged body parts (Bellamy 1992). The first was that of a double burial of an adult male and a child of about 10-12 years, the second was that of a triple burial of two adults (one male, one female) and an infant. In both cases the bones were neatly separated and stacked in piles. Here, coffins may have been chosen for these burials as they could be more easily re-opened to permit the re-sorting of the bones.

The observation that multiple bodies were found in coffins leads on to another intriguing aspect of these burials. Between 2400 and $1750 \mathrm{BC}$, the majority of bodies (both inhumation and cremation burials) were buried in single graves. However, when coffined burials are considered as an isolated subset, the number of double or triple burials is proportionally much higher. Beyond the example given above at Fordington Farm, at least three further examples of multiple burials in/with coffins of this date were identified in our case study areas (mainly in East Yorkshire), two of which were bi-ritual examples of 


\section{A. Cooper et al. COVERING THE DEAD IN LATER PREHISTORIC BRITAIN}

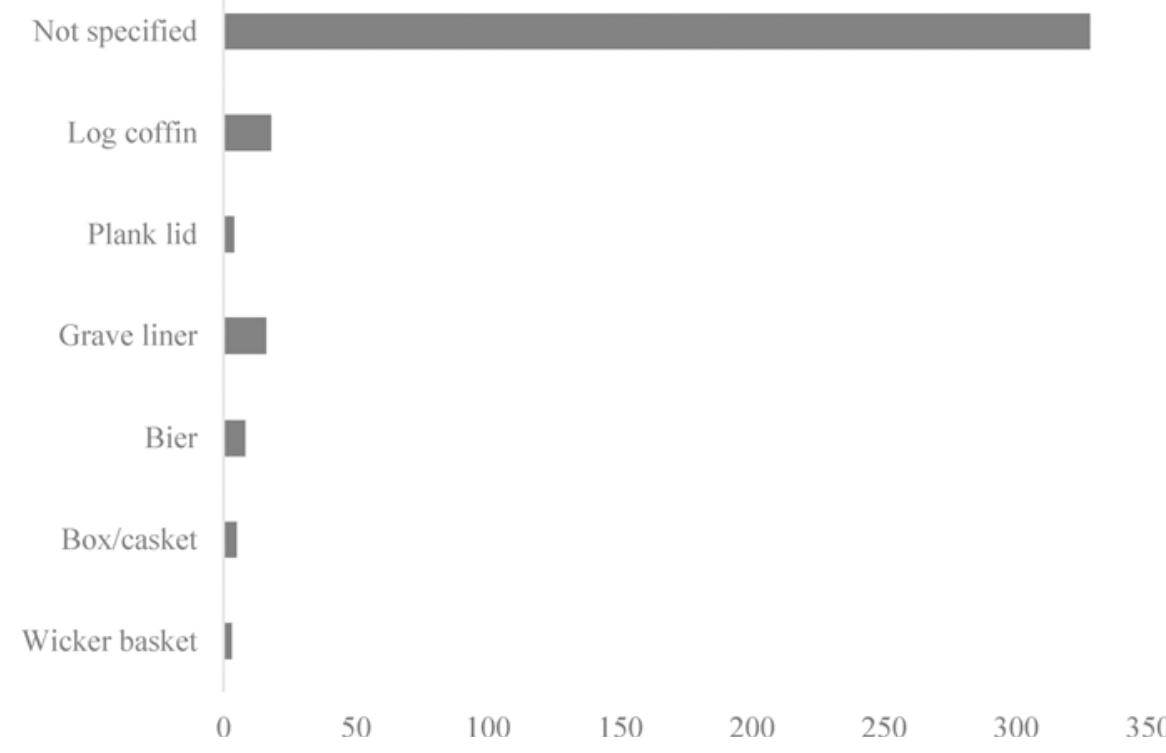

Fig. 5.

Different forms of timber container recorded in the Grave Goods database $(n=382)$

contemporaneous cremation and inhumation (see below). At Driffield Barrow 279a, East Yorkshire, a large split oak trunk coffin over $2 \mathrm{~m}$ long contained three skeletons (Mortimer 1905, 296-7), while at the nearby Honey Hill Barrow M296, two adult males, almost touching each other, were placed within a similarly large coffin (Greenwell 1877, 213-4). Another triple burial, this time comprising a primary child inhumation and two secondary adult cremations, was contained in the central oak-lined grave (or large decayed coffin) of Bishop Wilton Barrow 14 (Mortimer 1905, 157). In another possible example at Rudston Barrow 69, the feet of a supine male inhumation were covered with the cremated remains of a second male (Greenwell 1877, 269-71).

To summarise, the shape, size, and material of the coffin might have been chosen for specific symbolic reasons or funerary traditions, but nonetheless, as a container, it provided both a practical and hygienic solution when faced with a physical journey or temporal hiatus between death and burial. Additionally, it could be used to bring related or connected individuals into union in death, even where mere fragments remained - as much a charnel chamber as a family vault.

\section{Cremation burials in coffins and burnt coffins}

In contrast to the Iron Age, when all coffined burials contained inhumations, ten $(22 \%)$ EBA coffins in our case study areas contained cremation burials. These containers were often 'over-sized' for the small pile of burnt remains placed within them. The large lidded oak coffin in the centre of the mound of Towthorpe Plantation Barrow C73 was quite empty apart from the heap of cremated remains placed at one end (Mortimer 1905, 6). Similarly, the $1.3 \mathrm{~m}$ long boat-shaped oak coffin at Scrubbity Barrow 1, Dorset, only contained a small pile of cremated bones of an adult (Pitt-Rivers 1888, 32-4); there are several other examples of the coffin size appearing more suitable for an inhumation burial (eg, Bishop Wilton Barrow 100, Yorkshire; Mortimer 1905, 158; Latch Farm Barrow, Dorset Burial 3; Piggott 1938, 173).

In direct opposition to these discrete and restrained interments, at Rudston Beacon Barrow 272, East Yorkshire, a coffin over $1 \mathrm{~m}$ long was covered from top to bottom with a substantial deposit of cremated bone relating to more than one individual (Mortimer 1905, 343). Similarly, at Afflington Barrow, Dorset, a large deposit of burnt and 'pounded-up' bones was carefully arranged along the full extent of a wooden bier (Grinsell 1959, 103).

Notably, a significant proportion of EBA coffins (eight from our study areas, with others known elsewhere [eg, Ashbee 1986]) were slightly carbonised or singed: set aflame in a manner perhaps akin to Viking ship burials (indeed, some of the burnt 

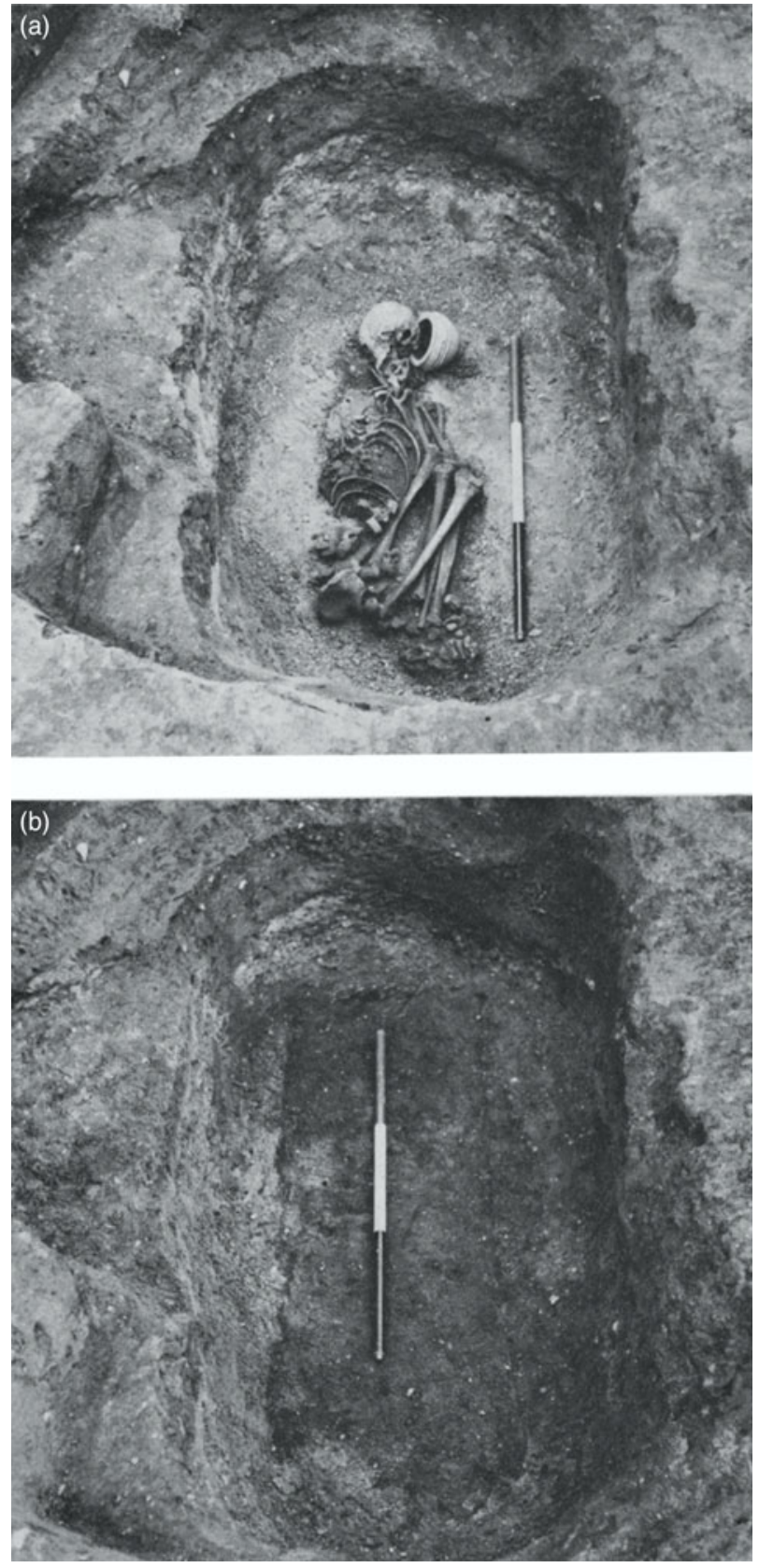

Fig. 6.

Coffin burial from Tallington, Lincolnshire (Simpson 1976, pl. 24): a. inhumation burial and Food Vessel; b. outline of the coffin prior to excavation. Simpson $(1976,223)$ noted that the body was probably trussed in a tightly bound position before being placed in the coffin. The skull was twisted round so that it faced backwards; a small Food Vessel was placed so that its mouth covered the back of the skull examples were boat-shaped and inserted into barrows on boggy ground, perhaps implying a close connection to water). In other cases, burning is more ephemeral, leading to charring around the edges and occasionally sooted or burnt associated grave goods. It could be argued that this was a hollowing-out and woodhardening technique relating to the crafting of the coffin itself, yet this seems unlikely: many bear the trace of tool marks indicating fine finishing with adze or axe. At Cherry Burton Barrow 72 the earth around the edges of the grave (containing a middle-aged male) was burnt, and the probable coffin was reduced to charcoal (Greenwell 1877, 280). While most of these burnt coffins contained inhumations, two from Dorset (Latch Farm and Afflington; Piggott 1938, 173; Warne 1866) and one from East Yorkshire (Wetwang Slack Area 16/WK8; Dent 2010, 100) contained cremation burials. Several of the singed coffins also contained piles of plant remains in the corner, including small branches and bracken - perhaps set on fire to create a highly performative event. Given the arguments made above regarding the transport of putrefying remains, this evidence could represent purification or cleansing rituals, or even relate to aromatic smoking or symbolic mummification/preservation of the bodies. Whatever the motivation, even these short-lived mortuary fires would have been visually dramatic, seen by mourners over extended distances.

Additionally, it is worth highlighting that the period during which coffins became prevalent in the EBA represents a transitional phase of mortuary practice more generally (Fig. 7). Although both inhumation and cremation burial were commonly practiced between 2150 and $1750 \mathrm{BC}$, cremation burial ultimately overtook inhumation as the primary burial rite during this period. The rise of urns as burial containers follows closely that of cremation burial. The occurrence of coffins, however, remains broadly stable, perhaps because they were able to operate as containers for either/both inhumation and/or cremation burials. It is possible that the notion of how to contain and what might be contained in burials also underwent significant ideological transformation at this time. Coffins appear to have become caught up in - and, to some extent, perhaps even to have flourished because of - these wider changes. This phase of transition possibly explains the coffin-related 'oddities' that stand out to us as unusual - cremated remains being placed in 


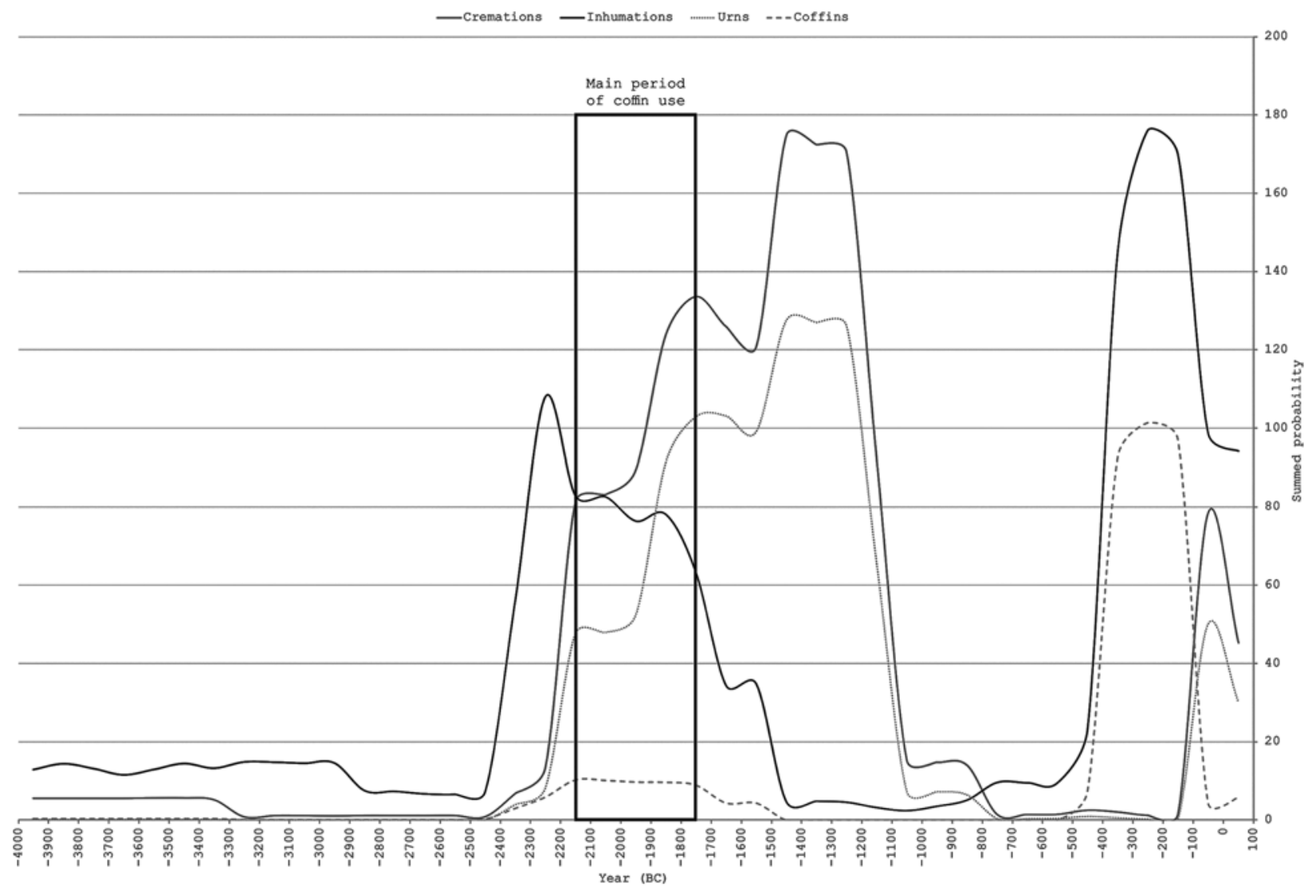

Fig. 7.

Fuzzy temporal distribution of inhumations and cremation burials, and of pottery and coffins used directly to contain human remains, in the Grave Goods database. The summed probability value (y-axis) represents a sum of the \% likelihood that each recorded entity (a cremation/inhumation/urn/coffin) can be attributed to a given 100-year time-slice ( $\mathrm{x}$-axis) over the entire study period. Very specifically dated entities may have a $100 \%$ likelihood of belonging within a 100 -year time slice; the values for vaguely dated entities - often the case for later prehistoric evidence - are distributed between the relevant timeslices (see Green 2011 for details of this fuzzy temporal distribution method)

containers that were apparently much more suitable for inhumations, and the burning of coffins as part of what was perhaps a newly introduced ritual aspect of burial performance involving fire.

\section{COVERING COMPANIONS: INDIRECT EVIDENCE FOR COVERING AND CONTAINMENT}

This section moves away from such clear architectural devices for containing the dead, and towards more ephemeral evidence - a category of objects that we have termed 'covering companions'. We will begin by focusing on one particularly clear example. The excavation of the MIA chariot burial at Wetwang Village (Hill 2004) revealed three objects, amongst many others, that we would like to look at specifically
(Fig. 8): a string of beads, a bow brooch, and a strap union. These formed part of a materially-rich burial assemblage that accompanied an elderly woman, including, most famously, a dismantled chariot together with its fittings (Giles 2012, 245-9). We can highlight many interesting details about the material makeup of the beads, the brooch, and the strap union - how they were put together, their life histories, the ways in which they might have been used or understood prior to the funeral (ibid.). The emphasis here, however, is on what these objects were doing at the time they were deposited. The strap union is thought to have pinned a body bag the dead woman's left hand was bent back so tightly that it may have fractured post-mortem (Hill 2004 and pers. comm.). The string of beads may have adorned the neck of a fur-lined bag (potentially fashioned from 


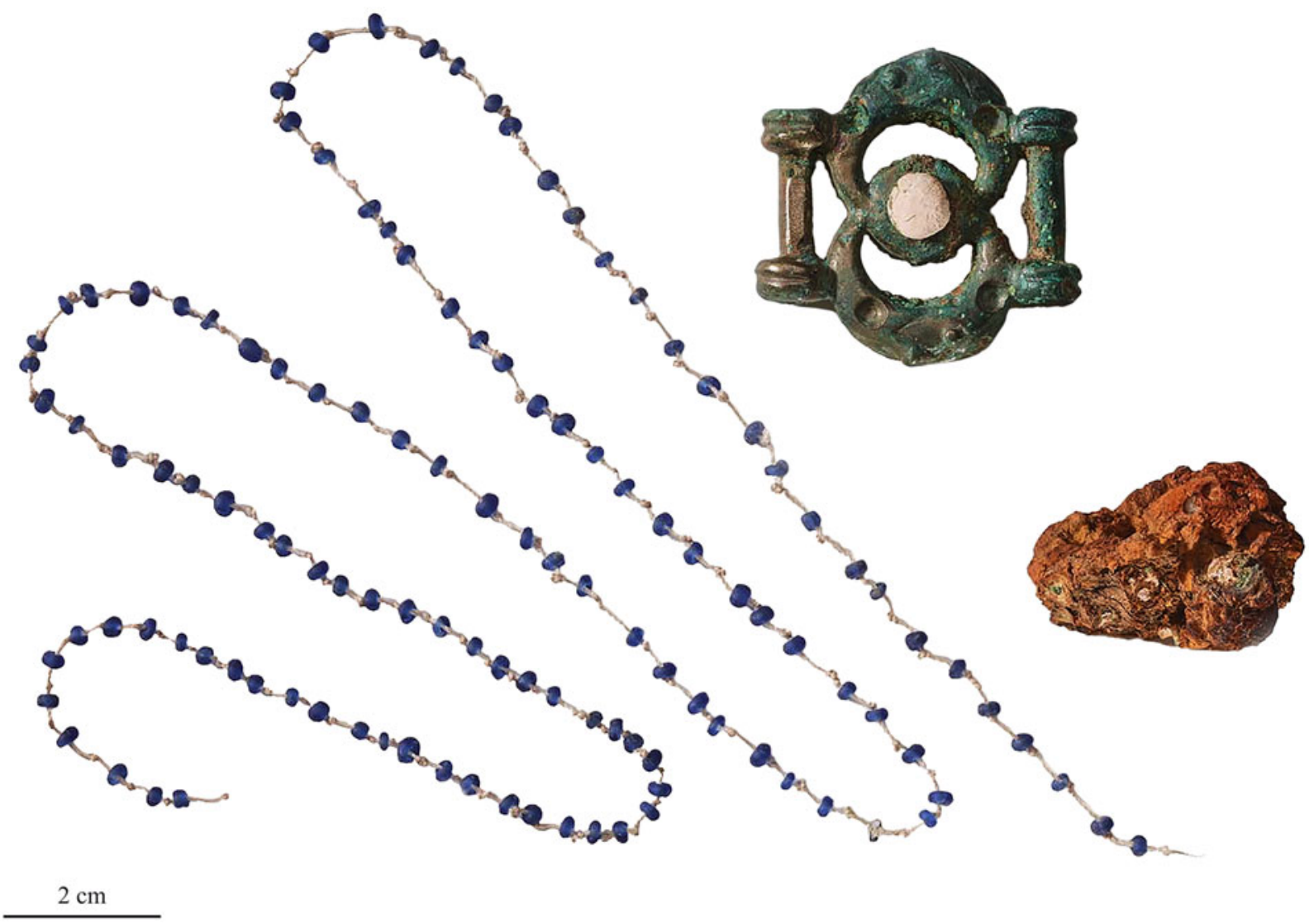

Fig. 8.

Covering companions from Wetwang Village, East Yorkshire (@ Trustees of the British Museum): a. involuted bow brooch; b. strap union; c. strand of miniature blue glass beads

an otter's pelt) containing an iron mirror. They were also wound tightly around the iron brooch, which could itself have pinned the bag. These intriguing objects draw our attention to the central role of covering and containment in this burial. Although they are not covers or containers in their own right, they were vital companions to absent and present organic covers within this grave assemblage - they operated practically to fix these in place and played a role in creating the aesthetics of the burial performance.

We can recall other covering companions from the exceptionally well-preserved EBA burials discussed above - the awl pinning together the bearskin holding the cremated remains at Whitehorse Hill (Sheridan et al. in Jones 2015); the bone pin which fixed the hides wrapping Gristhorpe Man (Melton et al. 2010; 2013); and even the four stones weighing down the cow skin that enveloped the woman buried at
Langwell Farm (Lelong 2014). At one level, covering companions such as these should be recognised as potentially powerful objects in their own right - they provided a point of connection between the people undertaking the covering and the person or thing that was covered; they may effectively and conceptually have been thought to hold in or keep out potentially dangerous forces, and could also have determined future revisiting and uncovering. Additionally, and importantly in the context of this paper, covering companions can make visible covering practices well beyond burials with exceptionally well-preserved organics. In the next section, we explore the significant potential of covering companions, investigating what they can tell us about otherwise 'invisible' covering and containment in prehistoric funerals.

Most previous accounts of covering companions in graves have commented on them only in passing or as 


\section{A. Cooper et al. COVERING THE DEAD IN LATER PREHISTORIC BRITAIN}

part of wider object-specific analysis (see however Giles 2012). Woodward and Hunter $(2015,517)$ identified several objects which may have been used to pin bags and cloths around EBA cremated remains. Complementing Giles' (2012) exploration of the multiple roles of brooches and other fasteners in MIA burials in East Yorkshire (see also Adams 2013), Edgar (2012) developed a careful method for identifying what brooches were doing in burials in northern France in the later Iron Age. Covering companions from Neolithic, LBA/EIA, and LIA graves in Britain have received little interpretative attention. There has also been a tendency to assume that the role played by objects prior to their deposition is echoed directly by the role that they played in burial. This is particularly the case with pins and brooches where arguments for their significance as 'costume' items in life (eg, Fitzpatrick 1997a; Woodward \& Hunter 2015) have, to some extent, eclipsed the possibility that some of these objects may well have operated quite differently within funerary contexts.

Our own approach to covering companions was deliberately open-minded. We considered objects that have traditionally been understood either as dress accessories or as shroud/cremation bag fasteners (eg, pins, brooches, points) but also objects that are not usually understood in this way. This includes items that Woodward and Hunter $(2015,357)$ thought may have been used to pin cloths or bags containing cremated remains (eg, awls, teeth/tusks, daggers/ knives), and items which almost certainly had other purposes prior to the funeral but which then became fasteners for bags or containers (eg, pendants, strap fittings, toggles; see for example Owen 1889; Hill 2004; Jones et al. 2011, 93) (Appx S1). Overall, 18 different object types were considered as potential covering companions, comprising 946 objects in total (c. $18 \%$ of the Grave Goods dataset).

In addressing this evidence set, it is important to highlight, firstly, that the organic items which might help us to distinguish between items associated with clothing and items that effectively helped to conceal the body are often missing. Secondly, many potential covering companions, particularly those recovered from EBA barrows, were excavated by antiquarians and thus lack relevant information - good contextual detail was available for $71 \%$ of the objects under consideration. Additionally, $8 \%$ (61) of these object types were burnt, potentially on the cremation pyre. The role of these burnt objects in funerary processes is especially elusive, although it is possible that at least some of the pins, brooches, points, and unknown metal objects (often interpreted as melted fasteners) held together shrouds and other covers rather than clothing. It is therefore important to acknowledge the necessary ambiguity involved in investigating covering companions and to take care in approaching them interpretatively.

Two main levels of investigation were undertaken. Object types that were made primarily for pinning covers in graves (staples, collars) or which have commonly been interpreted as garment or shroud fastenings (brooches, pins, points, needles) were subject to broad-scale digital analysis using the criteria summarised in Table 3. Objects that appear to have operated only very rarely as covering companions, and which could play other roles in burials (eg, awls, beads, buttons, daggers), were examined separately on a case by case basis. For both levels of investigation, a good understanding was required of how potential covering companions were positioned relative to the body (and to other objects in the grave). Clearly therefore, only potential covering companions from burials with reasonable contextual information were considered analytically. Where organic traces were preserved, these often provided complementary evidence. As Giles (2012, 129-30) observed, body position is sometimes a helpful indicator of whether or not an inhumed skeleton was tightly bound (and thus perhaps fastened) upon burial. Similarly, the tight clustering of cremated remains can indicate interment in a bag.

Although in most cases a single covering companion was used to fix a single body or set of objects in the grave, covering companions also sometimes operated in pairs or in groups. For instance, in LIA cremation burials in Kent, pairs of brooches sometimes book-ended deposits of cremated bone (eg, in Burial 13 at Swarling, Kent; Bushe-Fox 1925, 6) and of objects (eg, the mirror at Chilham, Kent; Parfitt 1998, 345). In order to handle this complexity for the broad-scale analysis, objects operating collectively in this way were counted only once. Regarding the case by case analysis of more unusual covering companions in inhumation burials, it was only very rarely possible to argue convincingly that these fastened shrouds or wraps rather than fulfilling some other purpose. However the fact that the same set of objects regularly occurs in an unburnt state on top of cremation burials does support the idea that they were sometimes used to fasten cremation bags/wraps. 
THE PREHISTORIC SOCIETY

TABLE 3. METHOD FOR IDENTIFYING POTENTIAL COVERING COMPANIONS IN THE GRAVE GOODS DATASET

\begin{tabular}{|c|c|c|c|}
\hline Burial type & $\begin{array}{l}\text { Rating as } \\
\text { covering } \\
\text { companion }\end{array}$ & $\begin{array}{l}\text { Position of fastener relative to } \\
\text { buman remains/objects }\end{array}$ & Notes and suggestions for more specific roles \\
\hline \multirow{3}{*}{ Cremation } & Likely & $\begin{array}{l}\text { Directly outside/on top of/below } \\
\text { heap of cremated remains }\end{array}$ & $\begin{array}{l}\text { Includes on top of/below heap of cremated remains in } \\
\text { or out of container (an adaptation of Edgar 2012; } \\
\text { Woodward \& Hunter 2015) }\end{array}$ \\
\hline & Unlikely & $\begin{array}{l}\text { Separate to cremated remains } \\
\text { (sometimes in or under a pot) } \\
\text { Amongst scattered remains }\end{array}$ & $\begin{array}{l}\mathrm{n} / \mathrm{a} \\
\text { The human remains are often disturbed in such } \\
\text { instances }\end{array}$ \\
\hline & Potential & $\begin{array}{l}\text { In container with cremated } \\
\text { remains/within separate heap of } \\
\text { cremated remains }\end{array}$ & $\begin{array}{l}\text { Edgar (2012) records these straightforwardly as items } \\
\text { of dress/adornment added to the cremation deposit } \\
\text { separately as grave goods. However, in most cases it is } \\
\text { difficult to be so specific. It is also possible that a } \\
\text { fastener holding loosely bagged cremated remains } \\
\text { could end up amongst rather than separate from the } \\
\text { bones (see for example the pendant from Harlyn Bay; } \\
\text { Jones et al. 2011) }\end{array}$ \\
\hline \multirow[b]{2}{*}{ Inhumation } & Unlikely & $\begin{array}{l}\text { Hands } \\
\text { Ears/neck } \\
\text { Upper torso/arms }\end{array}$ & $\begin{array}{l}\text { Separate grave good } \\
\text { Likely clothes fasteners }\end{array}$ \\
\hline & Potential & $\begin{array}{l}\text { Back of head } \\
\text { Front of face } \\
\text { Beyond the body } \\
\text { Calves } \\
\text { Feet } \\
\text { Lower torso } \\
\text { Thighs }\end{array}$ & $\begin{array}{l}\text { A cloak drawn over the head/face } \\
\text { Pinning a cloak drawn over the head/face } \\
\text { Pinning a bag of objects; separate grave good }\end{array}$ \\
\hline $\mathrm{n} / \mathrm{a}$ & Likely & On/outside a group of objects & $\begin{array}{l}\text { Pinning a bag around an object (eg, a mirror)/set of } \\
\text { objects }\end{array}$ \\
\hline
\end{tabular}

Draws on approaches developed by Edgar (2012); Woodward \& Hunter (2015; cremation burials); Giles (2012; inhumations)

TABLE 4. POTENTIAL ROLE OF COMMON COVERING COMPANIONS IN THE GRAVE GOODS DATASET (\% OF ALL POTENTIAL COVERING COMPANIONS)

\begin{tabular}{|c|c|c|c|c|}
\hline \multirow[b]{2}{*}{ Role } & \multicolumn{2}{|c|}{ Inhumations } & \multicolumn{2}{|c|}{ Cremation burials } \\
\hline & $E B A(n=20)$ & $M / L I A(n=176)$ & $B A(n=36)$ & $\operatorname{LIA}(n=35)$ \\
\hline Likely role in covering a body/bodies & 20 & 1 & 17 & 17 \\
\hline Likely role in covering an object/objects & 5 & 4 & - & 3 \\
\hline Ambiguous role in covering a body/an object/objects & 15 & 38 & 55 & 54 \\
\hline Unlikely role in covering a body/an object/objects & 60 & 57 & 3 & 14 \\
\hline Burnt (possible pyre good) & - & - & 25 & 12 \\
\hline
\end{tabular}

The findings of this study are summarised in Table 4, Figures 9-10, and Appx S2. Objects that operated commonly as covering companions and/or as garment fastenings in prehistoric burials include 64 pins, points, and needles from mostly EBA burials and 284 brooches, collars, needles, pins, points, and staples from M/LIA burials (348 objects in total,
Fig. 9). Broad-scale analysis of this evidence showed that in both EBA and M/LIA inhumation burials, fasteners are frequently found in positions that are not compatible with in situ clothing (Table 4, Fig. 10). While this point has been made previously for MIA burials in East Yorkshire (Giles 2012, 129), it is clearly valid more widely. Even more positively, 


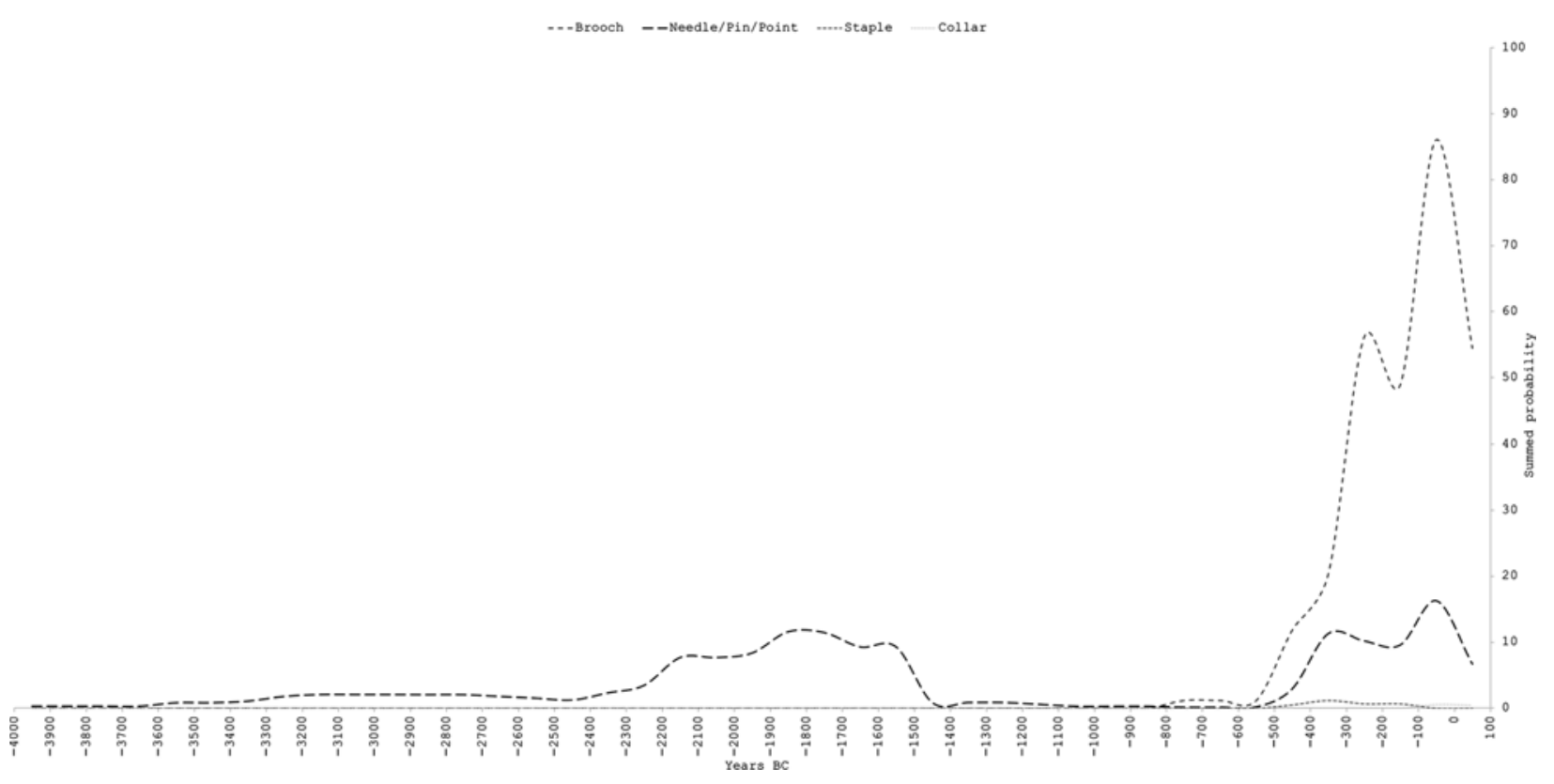

Fig. 9.

Fuzzy temporal plot of the incidence of objects identified commonly as covering companions in prehistoric burials from 4000 BC-AD 43 ( $n=441)$ (see Fig. 7 for a summary of the fuzzy temporal distribution method)

in Bronze Age and LIA cremation burials, c. 15-25\% of pins, points, brooches, and collars were found in positions that suggest they could well have operated as covering companions; most of these objects appeared likely to be fixing organic cremation sacks. Overall, although it is difficult to interpret this evidence definitively, it does strongly suggest that the frequency of covering in prehistoric burials has previously been significantly underestimated.

In the remainder of this section, we focus more specifically on the 48 objects (from 34 separate graves and incorporating 13 different object types) which seem most likely to have operated as covering companions in burials (Appx S2).

A single likely example of a covering companion was identified amongst our Neolithic burials - at Cowlam Barrow 57, East Yorkshire, a bone pin was found directly in front of the face of an elderly woman and may well have fastened a shroud (Greenwell $1877,214-21$ ). The single likely covering companion identified for the Beaker period fixed together a bag of objects rather than a body - this pin was found on top of a cluster of four finely worked flints behind the back of an elderly lady in Rudston Barrow 61 (Greenwell 1877, 229-32). The paucity of evidence for covering companions in the Beaker period is perhaps particularly interesting given that burials of this period were relatively rich materially. This could suggest that coffins (see above), rather than organic wraps, etc, were the primary means of covering the dead at this time.

Almost half of the graves that produced convincing covering companions were EBA in date. These examples were widely spread geographically, although no covering companions for this period were found in our Kent or Orkney/Outer Hebrides study areas. This is also the period during which the greatest variety of objects were used to fix covers in burials - pins and points, but also toggles, awls, buttons, a pendant, wire, and possibly a flint knife. This raises the important point that the primary purpose of objects was often transformed in the burial context. For instance, an awl, previously potentially used for puncturing leather or for tattooing the body (Woodward \& Hunter 2015, 501), adorned and fixed the cremation sack within the burnt log coffin at Latch Farm, Dorset (Piggott 1938, 173). It is also notable that, amongst EBA burials, there is little sense of standardisation in relation to the objects used as covering companions. One notable exception is the series of five infant burials within Garton Slack Barrow 112 (Mortimer 1905, 245-6), four of which were accompanied by 


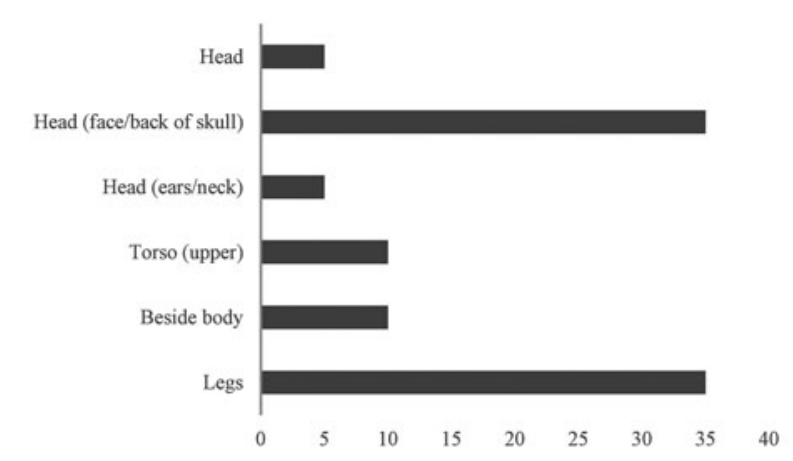

Position of EBA pins, points and needles in inhumation burials $(n=20)$

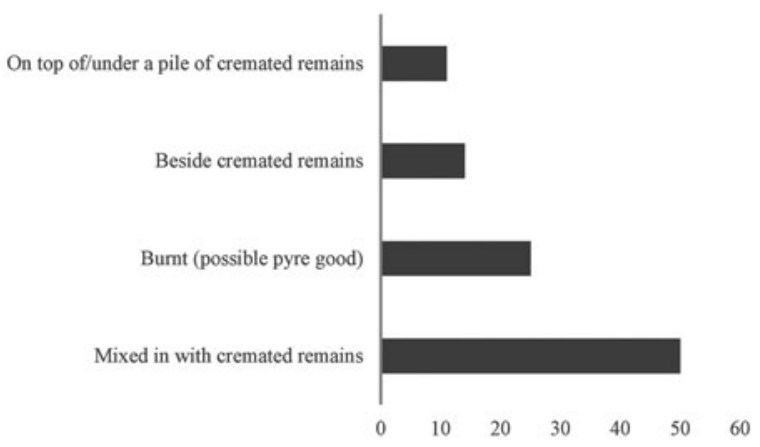

Position of Bronze Age pins, points and needles in cremation burials $(n=36)$

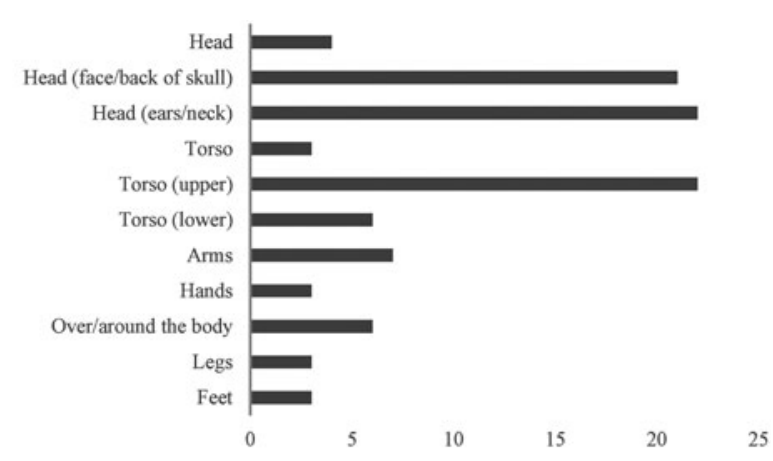

Position of M/LIA brooches, pins, points and staples in inhumation burials $(n=176)$

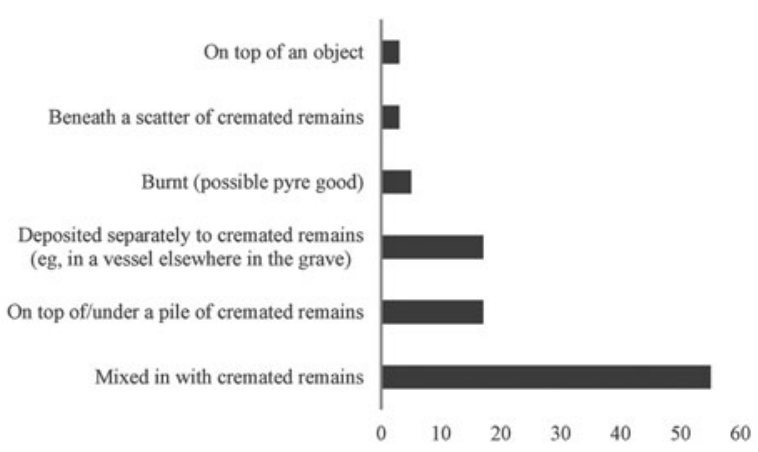

Position of M/LIA brooches, collars, pins, points and staples in cremation burials $(\mathrm{n}=35)$

Fig. 10.

Position of common covering companions with good contextual information in Bronze and Iron Age burials (expressed as a $\%$ of all potential covering companions)

bone pins/points, all found by the legs. It is certainly possible that this represents a local tradition of wrapping infants in shrouds and pinning them in a specific way before their burial.

In relation to M/LIA burials, beyond the exceptional examples from Wetwang Village described above, a narrower range of covering companions was identified, including brooches, points, pins, and items specifically made for fastening shrouds - staples and collars. A more standardised approach to fixing cloth covers in burials appears to have developed in this period. During the MIA, only in East Yorkshire were shrouds on inhumation burials fastened in an archaeologically visible way. Meanwhile, in the LIA, inhumations, cremation burials, mirrors and unknown (organic) items were pinned into sacks or shrouds in Cornwall, Dorset, and Kent. For instance, in the cremation burial at Bridge, Kent, a brooch pinned the cremation sack which was itself contained within an upturned bronze helmet (Farley et al. 2014, 381). The wrapping of Iron Age mirrors has been discussed widely (Joy 2010; 2011, 477; Giles 2012, 157) and is, notably, a practice that spans a long time period and wide geographical area. It is also of note that mirrors are the only object type that was consistently wrapped and fixed with brooches in LIA burials.

Additionally, it is worth observing that very few of the covering companions identified within our dataset were particularly out of the ordinary, at least from an archaeological perspective. The gold wire potentially 


\section{A. Cooper et al. COVERING THE DEAD IN LATER PREHISTORIC BRITAIN}

stitching together the hides which tightly bundled the beheaded inhumation burial at King's Barrow, Arne, Dorset is one possible exception in this respect. However, the manner in which this burial was excavated hinders an understanding of what the gold wire was doing and the funerary processes involved (see Needham et al. 2006, 103-4 for further details). The toggle probably holding together a bag of EBA cremated remains, and possibly also strung onto a cord connecting a pair of incense cups, in a burial pit at Flagstaff Quarry, Anglesey was finely finished and decorated (Owen 1889; Lynch 1970, 156). Similarly, the brooches pinning the cloth around the mirror in the grave at Portesham Farm, Dorset were of a highly unusual type with applied zoomorphic decoration (Fitzpatrick 1997b). However, there is no clear sense that covering companions 'stole the show' in burial performances, even if they were considered to be powerful objects in their own right.

In summary, we have brought to the fore how covering companions can offer important insights into covering and containment in prehistoric burials. This study has highlighted many examples beyond the well-known instances from exceptionally well-preserved prehistoric burials. It has also demonstrated the importance, in seeking to appreciate covering practices more fully, of looking beyond the (often elusive) organic items that wrapped bodies and objects directly. It is important to stress that the examples given here are almost certainly just the tip of an iceberg. Given the high standards of contemporary excavations, it is likely that further intriguing examples of covering companions will come to light in future. Finally, this analysis emphasises the importance of taking a critical yet open-minded approach to interpreting what objects did in prehistoric burials. Many of the covering companions mentioned here were probably used quite differently prior to their involvement in the funeral. Significantly, their purpose was transformed in the burial context - beads, awls, a knife, and a strap union, as well as pins and brooches, potentially became caught up in the performance of covering prehistoric bodies and objects. It is certainly possible that such object transformations were a desired part of the burial process. It is generally recognised that objects were sometimes transformed - via their destruction and fragmentation - in burial contexts (Jones 2010; Brück 2019, 112). However, the idea that objects were also transformed (practically and symbolically) on purpose - while remaining broadly intact has rarely, if ever, been discussed.

\section{CAPPINGS}

The final theme of our paper is that of capping: a form of concealment which was sometimes a means of sealing off burial performances, but was also potentially permeable, through lifting or uncovering. Cappings within graves have received very little previous analytical coverage, and many of the objects involved were almost certainly discarded by antiquarian excavators. The most commonly observed capping practice was lids or stoppers being used to cover the mouths of pots containing cremation burials, or placed under the mouth when the vessel was inverted. These make an appearance in late Food Vessel and Collared Urn burials, and become increasingly frequent in the MBA. In our study areas, 125 examples of lids were identified with distinct concentrations in Dorset in the MBA and, more generally, along the west coast of Britain in Cornwall, Gwynedd, and Orkney/Outer Hebrides. Lids were fashioned from a diverse set of materials including stones of various types, wood, textile, clay, and even a limpet shell. In at least one case, at Bed Branwen, Gwynedd, the lid was also sealed to the urn with clay (Lynch 1972). Other noteworthy examples include the use of sandstone from Dorset river valleys to cap MBA urned cremation burials in cemeteries on the upland heaths, several kilometres away (eg, White 1981). At Bagber Barrow, Dorset (Grinsell 1959, 119), and also potentially at Boleigh Barrow, Cornwall (Edmonds 1862, 30), a quern operated as an urn lid (Fig. 11). Meanwhile, an incense cup placed beneath the head of an inhumation burial in a barrow at East Lulworth, Dorset was capped simply with a limpet shell (Warne 1866, 10).

The placement of flat stones or concentrations of pebbles on top of burials has also likely been underrecognised in past excavations: in many instances these were considered not to be deliberate offerings but simply part of the backfill. Yet in some of the better-recorded examples, there is clear structure in the placement of these inorganic objects and potential meaning in the selection of the stone itself. The Neolithic chambered cairn of South Clettraval, North Uist, was reused in the Beaker period (Beveridge 1911, 189-90). A quantity of cremated bone, possibly representing more than one individual, was placed on the chamber floor near the entrance, accompanied by fragments of a Beaker. A number of carefully arranged quartz pebbles were placed on top of the bone, along with pieces of pumice (Henshall 1972, 506-11). 


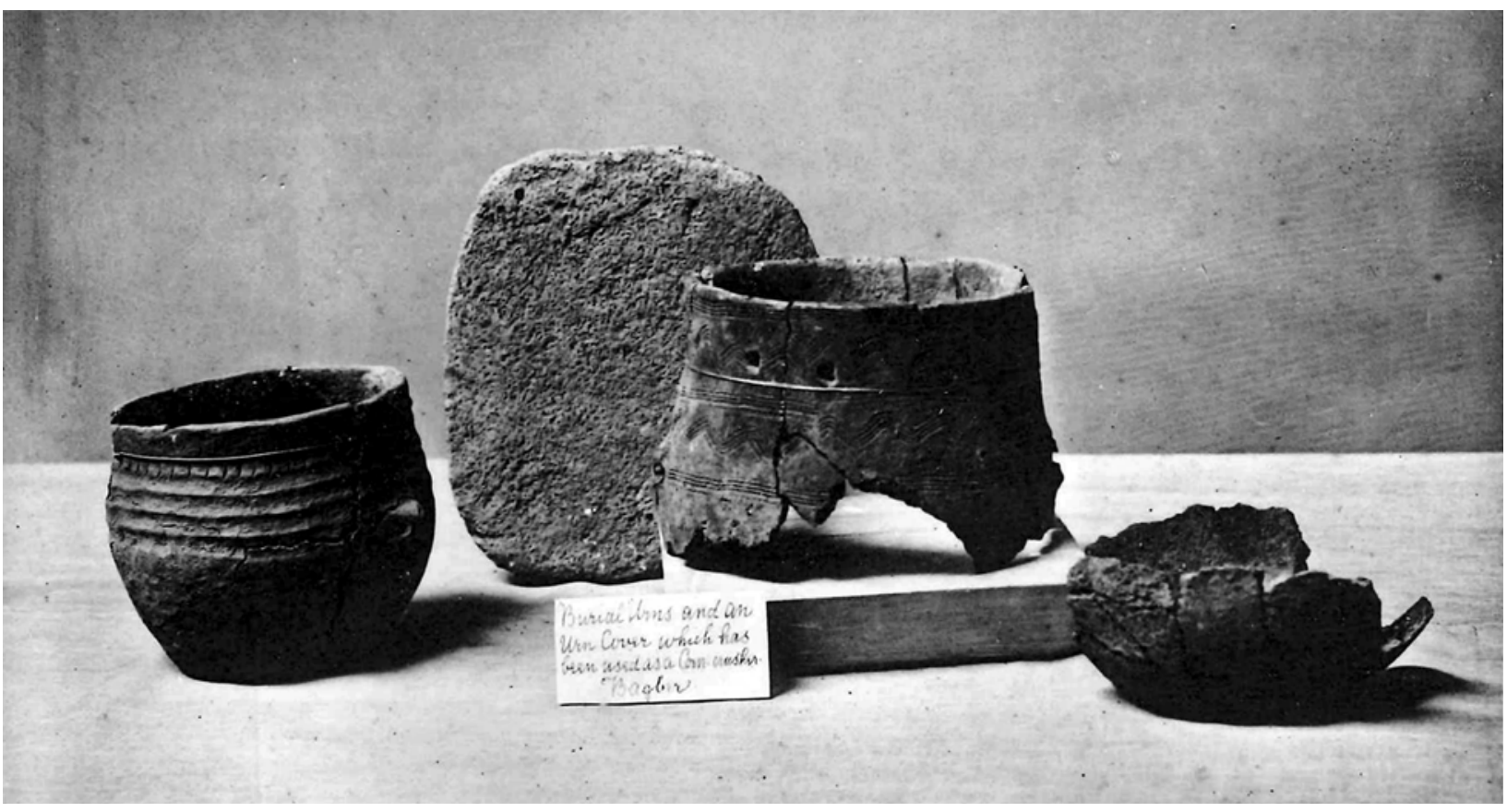

Fig. 11.

Quernstone lid from a MBA urned cremation burial at Bagber Barrow, Dorset. The label reads 'burial urns and an urn cover which has been used as a corn crusher, Bagber' (Mansel-Pleydell 1896)

Similarly at Llandegai, Gwynedd, several Late Neolithic cremation pits in close association with Henge A contained deliberately arranged stone settings (Lynch \& Musson 2001, 45-7, fig. 12). One arc-shaped pit, containing a small quantity of cremated bone (representing an adult and an infant), was lined with cobbles. The cremation was then covered by two burnt oak planks and a concentration of rounded beach pebbles placed on top of the wood. Intriguingly, the deposit was further capped by a large, flat, but broken, rock (perhaps originally a standing stone) that had seemingly been pushed over from an upright position and shattered on impact into this pit (Lynch \& Musson 2001, 51).

Stones and pebbles were also used to cover, hide, or protect the body, with a particular focus on quartz in Cornwall, Kent, and the Outer Hebrides. The symbolic qualities that quartz may have been endowed with in the past (eg, dazzling, protective, healing see Warren \& Neighbour 2004) highlight its potential significance within the funerary domain. Flint and chert were also used to cover bodies. At Godmersham, Kent, a tightly crouched EBA inhumation was placed in a shallow pit; a group of unworked flints had been placed across the lower part of the face and the corpse almost completely covered with a layer of compacted chalk (Bradshaw 1968, 253). Thus, stone was used particularly in the Neolithic and EBA periods as a cairn-like heavy covering, perhaps speaking of connections between the place of burial and other locales (see Brück 2004, 321; 2019, 170-1); its aesthetic properties hardness, colour, texture, or sheen - might also have been important. In other burials, shell was used as part of an admixture of substances. The Neolithic burial at Nethercourt Farm, Kent was covered in crushed pottery, charcoal, and oyster shell (Stebbing 1951). In this case, perhaps the lustrous, delicate, and patterned nature of these materials, or even their sonorous and tactile qualities, heightened the covering-over of the corpse.

In contrast, a rare LIA burial (5176) from Caythorpe, East Yorkshire, was lain upon and 'packed around with a cairn of roughly hewn white chalk blocks, almost forming a cairn around the body' (Fraser \& George 2013, 80; Steedman et al. forthcoming). Whilst described elsewhere in the report as a 'stoning' (linked to the weighting down of corpses that might rise from the dead in the Anglo-Saxon period; Steedman et al. forthcoming, 189), we do see this practice elsewhere in Iron Age contexts such as at Danebury, where both flint and chalk blocks pinned down a variety of individuals and body 
A. Cooper et al. COVERING THE DEAD IN LATER PREHISTORIC BRITAIN

(a)
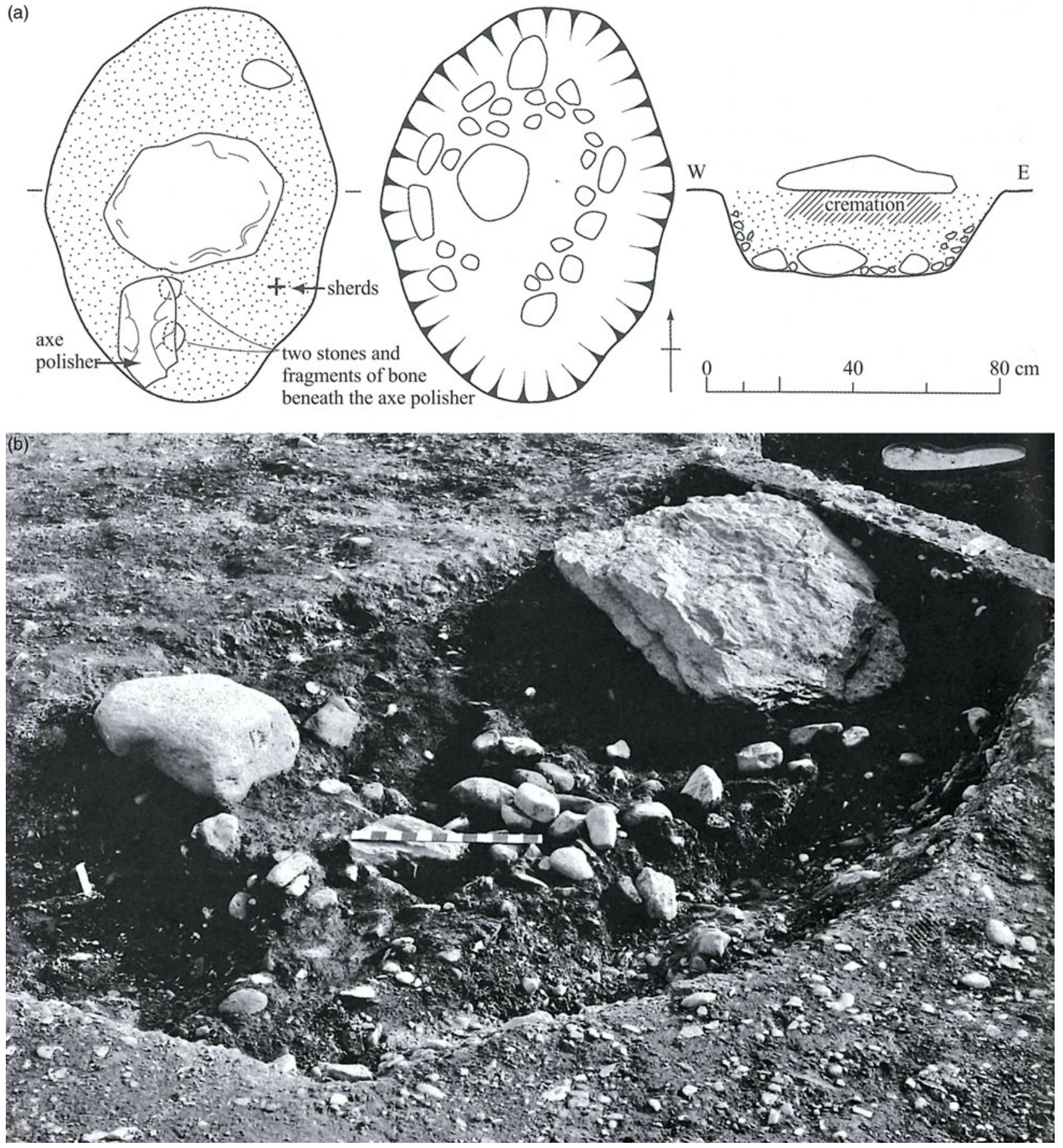

Fig. 12.

Middle Neolithic capped cremation burials at Henge A, Llandegai, Gwynedd (Lynch \& Musson 2001, figs 18 \& 23) (reproduced courtesy of Frances Lynch): a. Pit FA370 - cremation burial with coverstone and axe polisher; b. Pit ACC2 cremation burial covered with an oak plank, non-local pebbles, and fragments from a smashed block of metamorphic rock 
parts at the base of pits (eg, Cunliffe 1984, 444). Yet the description of the chalk as base, border, and cairn suggest something subtly different at Caythorpe. In later prehistoric East Yorkshire, such chalky spreads would have evoked a strong set of meanings: broken up for daub mix, crushed to make roundhouse floors, and won from quarries to act as 'lime' on these soils, shrouding the body in chalk might have evoked the warmth of the domestic or the fertility of the soil.

Recent research on microbial decay and bone histology on skeletons from Iron Age 'pit burials' suggests that covers formed an important part of primary mortuary rites within the Wessex region. Booth and Madgwick $(2016,21)$ have suggested that 'textile or leather' covers may have been employed as a form of 'protected exposure' (or sheltered excarnation) to minimise weathering and scavenger modification whilst decay took its course within steep-sided storage pits, facilitating selective retrieval of body parts for secondary mortuary rites of interment, further curation, or display. Sharples $(2010,300)$ notes the disproportionate amount of violence meted out to such bodies, suggesting at least some of them were enemies, exiles, mysterious, or unfortunate deaths, or those suspected of witchcraft or sorcery. In such a world, the covering-over but periodic revelation of the dead might have performed another function. It would have permitted 'death-workers' to periodically view and assess decomposition, perhaps at times when it was necessary to witness the mortal fate of an enemy, or to make sure that death was taking its natural course - for instance in cases where incorruptibility or the revenant were particular concerns.

The assemblage from Painsthorpe Wold Barrow 98, grave C (Kirby Underdale, East Yorkshire) touches upon many of the themes discussed in this paper: a 'glass coloured' narrow flint blade was found close to a decayed lump of black matter (possibly wood), a beaver's tooth, and a pair of black flint tools - a fine knife and a flake. These objects were clustered upon the chest of a tall, slender woman (Mortimer 1905, 132-3) - they may have been wrapped as a suite of grave goods. Close by the two overlapping black flints was a small 'Devil's toenail' fossil (Gryphea incurva), one of the 'overlooked' but significant objects that no doubt intrigued prehistoric people as much as us. The body itself may have been wrapped and pinned by the 'fine bodkin' of bone touching the spinal column. The fill of the grave contained many snail shells, including the boldly brown striped Helix [Cepaea] nemoralis (famous for its striped polymorphism). The incidence of these snail shells in the grave could be explained in various ways. It is possible that they got in naturally. However, Mortimer clearly felt that such occurrences were noteworthy in comparison to other sites he had dug (see also 1905, 323), and it is certainly conceivable, alternatively, that snail shells were deliberately gathered and employed as a means of adding colour and lustre to the grave covering.

\section{DISCUSSION: WRAPPING UP}

Covering and containment were powerful technologies of later prehistoric funerary performance. They helped stage and stagger the ritual of burial. They could be a practical way of gathering, protecting and containing human remains, but also helped mediate emotions related to loss - materialising care for the dead. These processes were no doubt at times tender and respectful, at others appalling and wrenching. Yet as some of the examples discussed above reveal, some capping and covering-up bore a sense of finality that could still be punctured, permitting the grave to be re-opened. It was also then a technique of power, through which the mourners' relations with the dead were drawn into sharp focus: an act through which their command over the corpse or largesse in the funeral was pronounced. The secrecy wrought by concealment might be used to underline age or gender differences amongst the living, but it may also have been a means of enhancing ritual authority. Wrapping sometimes gathered together a treasured collection, or helped distinguish personal possessions from gifts, but it could also be deployed to prepare and present things needed in the afterlife. It was also an apotropaically effective practice, which spoke of how the bonds between the living and the dead, and the domains of this world and the next, were negotiated. These practices also engendered a world of metaphors that could speak of the power to patrol that boundary - tucking up and covering over, stitching a rent, stoppering a void, nailing shut, putting a lid on it. The obverse of these acts of closure unwrapping, casting asunder, tearing up, exposing, and despoiling - could have been equally powerful, if darker, means of contesting, diminishing, or defacing the renown of the dead (Taussig 1999; Riggs 2014).

Our paper has made a series of methodological and interpretive points. Whilst certain kinds of coffin have previously been discussed at length, we hope to have brought out the tremendous variety that is actually 


\section{A. Cooper et al. COVERING THE DEAD IN LATER PREHISTORIC BRITAIN}

evident in terms of the container itself, the materials used, and body/bodies/body parts these objects contained. It is especially notable that coffins peak during the EBA coincident with a period of flux and transition in burial practices more generally - coffins came to be used perhaps because they helped negotiate these complexities. Wrapping with textiles or containment with wood, hide, or fleece, is much easier to identify in waterlogged contexts, and occasionally also where metal artefacts have taken on the imprint of these substances through corrosion. We have demonstrated that it is possible to extend our understanding of these covers beyond such well-preserved organics, using what we have termed 'covering companions' to identify the absent presence of bags, shrouds, and other materials. We also hope to have brought out the full range of capping objects and materials which became caught up in burial - stone, in particular, in its many and varied forms, appears to have been used in this role in a wide variety of ways.

With regard to wider discussions of burial in later prehistoric Britain, and our understanding of mortuary practice in general at that time, the realisation that (often now invisible) covers - for bodies and objects - may have been much more prevalent than previously recognised indicates that we may need to change the ways in which we actually envisage the body in burial - as something that was (much more often) wrapped, shrouded, covered, contained. We do not believe this was driven by concerns about the 'abject' nature of the decaying corpse: it was a physical yet deeply social and metaphorical mortuary strategy. The research outlined within this paper has also, by and large, been focused on artefacts that often come to be ignored in discussions of more impressive grave goods - the gold, the amber, the bronze - which usually dominated narratives of burial at this time. We hope to have made clear the value in bringing the less impressive, seemingly more mundane, items to the fore. When approached in the right way, these have substantial amounts to tell us as well, both in themselves and in terms of how we understand other aspects of the funerary repertoire. Perhaps one key attribute of covers is that, by definition, they nearly always relate clearly to something else - bodies, objects, or architectures. They therefore offer specific insight into aspects of funerary practices that people in the past paid close attention to, saw as being coherent, or wanted to accentuate, be this certain fragments or groupings of human bodies, a battle-worn sword, a beach-worn pebble, or a set of flint tools. Our point that sometimes objects-in-life came to have quite different uses and meanings as objects-in-death also serves as a reminder not always to take even those more impressive artefacts at face value - they could have been transformed into something else in the grave.

Conceptually, we have also sought to redefine grave goods to include the containers, cappings, bags, boxes, and wraps themselves as part of the offering made to the dead, contrary to some previous definitions (eg, Stead 1991; Kalif 2005). The coffin or urn is, after all, one of the major expenses we still expend upon the dead - we should not look upon it as mere mortuary infrastructure, especially given the quality of the weaving and woodwork, or effort in stone or shellgathering discussed above. These too were gifts. Our final conclusion is that the boundaries archaeologists seek to define between personal possessions, grave gifts, funerary architecture, and mortuary materials (eg, Harding 2016) are often impossible to discern with clarity, especially where - in the course of the funeral itself - objects move between arenas of use and meaning. We have thus also drawn wrapping or 'covering companions' into the conceptual fold of grave goods: marking the shift made by often mundane objects from pin or brooch to a pivotal role in securing the dead.

Acknowledgements This study was carried out as part of the AHRC-funded Grave Goods project: a collaboration between the Universities of Manchester and Reading and the British Museum [AH/N001664/1]. Data and regionallyspecific advice were provided by Cornwall, Dorset, Gwynedd, Humber, and Kent, Orkney and the Outer Hebrides Historic Environment Records and by CANMORE. Sophia Adams (University of Glasgow), Joanna Brück (University of Bristol), Julia Farley (British Museum), Susannah Harris (University of Glasgow), Jaqueline McKinley (Wessex Archaeology), and Stuart Needham provided extremely helpful advice on, and wider examples of, the practices under discussion. Valuable details about evidence from recently excavated and published sites were shared by Chris Evans (Cambridge Archaeological Unit), Grace Jones (Wessex Archaeology), and Ken Steedman (Humber Field Archaeology). Many of the ideas in this paper were aired initially at the project's Grave Matters conference, University of Manchester, June 2018. Chris Green (University of Oxford) undertook the digital modelling required for Figs $7 \& 9$. Finally, we would like to thank Neil Wilkin for his insightful comments on incipient versions of the article and the three anonymous referees for their positivity and helpful thoughts on fine-tuning the submitted version. The research data behind this paper are to be found within the Grave Goods project database which will be available from 
the end of the project via the Archaeology Data Service: https://doi.org/10.5284/1052206.

\section{SUPPLEMENTARY MATERIAL}

To view supplementary material for this article, please visit https://doi.org/10.1017/ppr.2019.8

\section{REFERENCES}

Adams, S. 2013. The First Brooches in Britain: From manufacture to deposition in the Early and Middle Iron Age. Unpublished PhD thesis, University of Leicester

Allen, T., Bates, A. \& Collins, J. 2012. A Road Through the Past: Archaeological discoveries on the A2 Pepperhill to Cobham Road-Scheme in Kent. Oxford: Oxford Archaeology Monograph 16

Ashbee, P. 1986. The excavation of Milton Lilbourne barrows 1-5. Wiltshire Archaeological \& Natural History Society Magazine 80, 23-96

Bailey, L., Green, M. \& Smith, M.J. 2013. Keeping the family together. Canada Farm's Bronze Age burials. Current Archaeology 279, 20-6

Banck-Burgess, J. 2014. Wrapping as an element of early Celtic burial customs: The princely grave from Hochdorf and the cultural context. In Harris \& Douny 2014, 147-56

Bellamy, P.S. 1992. The excavation of Fordington Farm round barrow. Proceedings of the Dorset Natural History of Archaeological Society 113, 107-32

Beveridge, E. 1911. North Uist: Its archaeology and topography, with notes upon the early history of the Outer Hebrides. Edinburgh: William Brown

Booth, T. \& Madgwick, R. 2016. New evidence for diverse secondary burial practices in Iron Age Britain: A histological case study. Journal of Archaeological Science 67(C), 14-24

Bradshaw, J. 1968. Investigations and excavations during the year. Archaeologia Cantiana 83, 253

Bristow, P.H.W. 2001. Behaviour and belief in mortuary ritual: Attitudes to the disposal of the dead in southern Britain 3500bc - AD43. Internet Archaeology 11. DOI: https://doi.org/10.11141/ia.11.1

Brown Vega, M. 2016. Ritual practices and wrapped objects: Unpacking prehispanic Andean sacred bundles. Journal of Material Culture 21(2), 223-51

Brück, J. 2004. Material metaphors: The relational construction of identity in Early Bronze Age burials in Ireland and Britain. Journal of Social Archaeology 4(3), 307-33

Brück, J. 2019. Personifying Prehistory: Relational ontologies in Bronze Age Britain and Ireland. Oxford: Oxford University Press

Bushe-Fox, J. 1925. Excavation of the Late-Celtic Urn-field at Swarling, Kent. London: Reports of the Research Committee of the Society of Antiquaries of London 5

Croucher, K. \& Richards, C. 2014. Wrapped in images: Body metaphors, petroglyphs and landscape in the island world of Rapa Nui (Easter Island). In Harris \& Douny 2014, 209-28

Cunliffe, B. 1984. Danebury. An Iron Age Hillfort in Hampshire. Vol. 2. The excavations 1969-78: the finds. London: Council for British Archaeology Research Report 52

Dent, J.S. 2010. The Iron Age in Eastern Yorkshire. Oxford: British Archaeological Report 508

Douny, L. 2014. Wild silk textiles of Dogon people of Mali: Wrapping and unwrapping material identities. In Harris \& Douny 2014, 173-92

Edgar, M. 2012. Beyond Typology: Late Iron Age and early Roman brooches in northern France. Unpublished PhD thesis, University of Leicester

Edmonds, R. 1862. The Land's End District: Its antiquities, natural history, natural phenomena and scenery. London: J.R. Smith

Evans, C., Tabor, J. \& Vander Linden, M. 2016. Twicecrossed River: Prehistoric and palaeoenvironmental investigations at Barleycroft Farm/Over, Cambridgeshire. The Archaeology of the Lower Ouse Valley 1. Cambridge: MacDonald Institute for Archaeological Research

Farley, J., Parfitt, K. \& Richardson, A. 2014. A Late Iron Age helmet burial from Bridge, near Canterbury, Kent. Proceedings of the Prehistoric Society 80, 379-88

Fitzpatrick, A. 1997a. Archaeological Excavations on the Route of the A27 Westhampnett Bypass, West Sussex, 1992. Volume 2: The cemeteries. Salisbury: Wessex Archaeology Report 12

Fitzpatrick, A. 1997b. A 1st-century AD 'Durotrigian' inhumation burial with a decorated Iron Age mirror from Portesham, Dorset. Proceedings of the Dorset Natural History or Archaeology Society 118, 51-70

Fraser, J. \& George, R. 2013. Archaeological Investigations at the Caythorpe Gas Storage Project, Low Caythorpe, East Riding of Yorkshire 2009-2010. Hull: Humber Field Archaeology

Gell, A. 1993. Wrapping in Images: Tattooing in Polynesia. Oxford: Clarendon Press

Gilchrist, R. \& Sloane, B. 2005. Requiem: The Medieval Monastic Cemetery in Britain. London: Museum of London Archaeology Service

Giles, M. 2012. A Forged Glamour: Landscape, identity and material culture in the Iron Age. Oxford: Windgather

Gleba, M. 2014. Wrapped up for safe keeping: Wrapping customs in Early Iron Age Europe. In Harris \& Douny 2014, 135-46

Green, C. 2011. Winding Dali's Clock: The construction of a fuzzy temporal-GIS for archaeology. Oxford: British Archaeological Reports S2234

Greenwell, W. 1877. British Barrows: A record of the examination of sepulchral mounds in various parts of England. Oxford: Clarendon Press

Grinsell, L. 1959. Dorset Barrows. Dorchester: Dorset Natural History \& Archaeological Society

Harding, D. 2016. Death and Burial in Iron Age Britain. Oxford: Oxford University Press

Harding, J. \& Healy, F. 2007. A Neolithic and Bronze Age Landscape in Northamptonshire. Swindon: English Heritage 


\section{A. Cooper et al. COVERING THE DEAD IN LATER PREHISTORIC BRITAIN}

Harris, S. 2014. Wrapping the dead: An investigation of the Bronze Age burial mounds of southern Scandinavia through a wrapping analysis. In Harris \& Douny 2014, 115-34

Harris, S. 2015. Folded, layered textiles from a Bronze Age pit pyre excavated from Over Barrow 2, Cambridgeshire, England. In K. Gromer \& F. Pritchard (eds), Aspects of the Design, Production and Use of Textiles and Clothing from the Bronze Age to the Early Modern Era, 73-82. North European Symposium of Archaeological Textiles XII. Austria: Budapest

Harris, S. \& Douny, L. (eds). 2014. Wrapping and Unwrapping Material Culture: Archaeological and anthropological perspectives. Walnut Creek, CA: Routledge

Henshall, A. 1972. The Chambered Tombs of Scotland. Edinburgh: Edinburgh University Press

Hendry, J. 1993. Wrapping Culture: Politeness, presentation and power in Japan and other societies. Oxford: Clarendon Press

Hill, J.D. 2004. Excavation of an Iron Age Chariot in the Village of Wetwang, East Yorkshire in May 2001. Unpublished report. London: British Museum

Hurcombe, L. 2014. Perishable Material Culture in Prehistory: Investigating the missing majority. London: Routledge

Jones, A., Marley, J., Quinnell, H., Hartgroves, S., Evershed, R., Lawson-Jones, A., Jones, S., Randall, C., Ratcliffe, L., Šoberl, L. \& Taylor, R. 2011. On the beach: New discoveries at Harlyn Bay, Cornwall. Proceedings of the Prehistoric Society 77, 89-109

Jones, A. 2015. Preserved in the Peat: An extraordinary Bronze Age burial on Whitehorse Hill, Dartmoor, and its wider context. Oxford: Oxbow Books

Jones, A.M. 2010. Layers of meaning: Concealment, containment, memory and secrecy in the British Early Bronze Age. In D. Boric (ed.), Archaeology and Memory, 105-20. Oxford: Oxbow Books

Jones, A., Brunning, R., Keefe, K. \& Holst, M. 2017. Recent radiocarbon dating and skeletal analysis of two log coffin burials from Yorkshire: Willie Howe and Towthorpe 139. Yorkshire Archaeological Journal 89(1), 61-74

Jones, A., Brunning, R. \& Wilkin, N. 2019. Loose Howe: A North Yorkshire log coffin boat burial(s) revisited. Oxford Journal of Archaeology 38(1), 1-15

Joy, J. 2010. Reflections on the Iron Age: Biographies of mirrors. Oxford: British Archaeological Report 518

Joy, J. 2011. Exploring status and identity in Later Iron Age Britain: Reinterpreting mirror burials. In T. Moore \& X. Armada (eds), Atlantic Europe in the First Millennium BC, 468-87. Oxford: Oxford University Press

Kaliff, A. 2005. The grave as concept and phenomenon. In T. Artelius \& F. Svanberg (eds), Dealing with the Dead: Archaeological perspectives on Scandinavian burial ritual, 125-42. Stockholm: National Heritage Board

Lelong, O. 2009. Langwell Farm, Strath Oykel Excavation Human Remains Call-off Contract: Data structure report. Glasgow: Glasgow University Archaeological Research Division (GUARD) Unpublished fieldwork report 2818
Lelong, O. 2014. Wrappings of power: A woman's burial in cattle hide at Langwell Farm, Strath Oykel. Proceedings of the Society of Antiquaries of Scotland 144, 65-132

Lynch, F. 1970. Prehistoric Anglesey: The archaeology of the island to the Roman conquest. Llangefni: Studies in Anglesey History 3

Lynch, F. 1972. Report on the re-excavation of two Bronze Age cairns in Anglesey: Bedd Branwen and Treiorwerth. Archaeologia Cambrensis 120, 11-83

Lynch, F. \& Musson, C. 2001. A prehistoric and early mediaeval complex at Llandegai, near Bangor, North Wales: Excavations directed by C.H. Houlder 1966-67. Archaeologia Cambrensis 150, 17-142

Manby, T.G., King, A. \& Vyner, B. 2003. The Neolithic and Bronze Age: A time of early agriculture. In T.G. Manby, S. Moorhouse \& P. Ottaway (eds), The Archaeology of Yorkshire: An assessment at the beginning of the 21st century, 35-114. Leeds: Yorkshire Archaeological Society Occasional Paper 3

Mansell-Playdell, J. 1896. On a Romano-British brick-kiln and a British barrow at Bagber, Milton Abbas, with an historical dissertation on pottery and brick-making. Proceedings of the Dorset Natural History \& Antiquarian Field Club 17, 130-2

Markovicky, N. 2014. Wrapping/unwrapping the body: Lace, magic, and modernity. In Harris \& Douny 2014, 97-114

Melton, N., Montgomery, J. \& Knüsel, C. 2010. Gristhorpe Man: An Early Bronze Age log-coffin burial scientifically defined. Antiquity 84(325), 796-815

Melton, N., Montgomery, J. \& Knüsel, C. 2013. Gristhorpe Man: A life and death in the Bronze Age. Oxford: Oxbow Books

Melton, N., Montgomery, J., Roberts, B., Cook, G. \& Harris, S. 2016. On the curious date of the Rylstone log-coffin burial. Proceedings of the Prehistoric Society 82, 383-92

Mortimer, J. 1905. Forty Years' Researches in British and Saxon Burial Mounds of East Yorkshire. London: A. Brown \& Sons

Needham, S., Parfitt, K., Varndell, G., Birchenough, A., Corke, B. \& Crummy, S. 2006. The Ringlemere Cup: Precious cups and the beginning of the Channel Bronze Age. London: British Museum Research Publication 163

Noble, G. \& Brophy, K. 2011. Ritual and remembrance at a prehistoric ceremonial complex in central Scotland: Excavations at Forteviot, Perth and Kinross. Antiquity $85,787-804$

Owen, E. 1889. Discovery of ancient British sepulchral remains at Penmon. Archaeologia Cambrensis 6(21), 59-63

Parfitt, K. 1998. A Late Iron Age burial from Chilham Castle, near Canterbury, Kent. Proceedings of the Prehistoric Society 64, 343-51

Parker Pearson, M., Sheridan, A. \& Needham, S. 2013. Bronze Age tree-trunk coffin graves in Britain. In Melton et al. 2013, 29-66

Piggott, C.M. 1938. A Middle Bronze Age barrow and Deverel-Rimbury urnfield, at Latch Farm, Christchurch, 
Hampshire. Proceedings of the Prehistoric Society 4(1), 169-87

Pitt-Rivers, A. 1888. Excavations in Cranborne Chase near Rushmore on the Borders of Dorset and Wiltshire. Volume II. Salisbury

Proctor, J., Gaimster, M. \& Young Langthorne, J. 2016. A Quaker Burial Ground in North Shields. London: PreConstruct Archaeology PCA Monograph 20

Riggs, C. 2014. Unwrapping Ancient Egypt. London: Bloomsbury Academic

Sharples, N. 2010. Social Relations in Later Prehistory: Wessex in the first millennium BC. Oxford: Oxford University Press

Simpson, W. 1976. A barrow cemetery of the second millennium B.C. at Tallington, Lincolnshire. Proceedings of the Prehistoric Society 42, 215-39

Stead, I. 1991. Iron Age Cemeteries in East Yorkshire: Excavations at Burton Fleming, Rudston, Garton-onthe-Wolds and Kirkburn. London: English Heritage Archaeological Report 22

Stebbing, W. 1951. Researches and discoveries in Kent. Archaeologia Cantiana 64, 15-1

Steedman, K., Fraser, J. \& George, R. forthcoming. Archaeological Investigations at the Caythorpe Gas Storage Project, East Riding of Yorkshire. East Riding Archaeologist 18

\section{APPENDIX: THE GRAVE GOODS PROJECT DATABASE}

The Grave Goods project database (ggdb) is a relational FileMaker Pro database that uses as its starting point information from Historic Environment Records (HERs) for the six project case study areas: (1) Cornwall (2) Dorset (3) East Yorkshire (Humber HER) (4) Gwynedd and Anglesey (5) Kent, and (6) Orkney and the Outer Hebrides (CANMORE, supplemented by information from individual island group HERs). The database was designed by the Grave Goods team in consultation with digital consultant Christopher Green, who also built it. Where possible (HBSMR-using and Welsh HERs), HER Monument, Event, Source, and Finds records were provided in $\mathrm{xml}$ or xls format for known or likely funerary sites (Appx S3) and sites where funerary-related terms were identified in descriptive fields (Appx S4), for the period 4000 BC-AD 43. In cases where individual HER officers identified significant potential for further funerary sites with grave goods to be identified beyond the key funerary site types (eg, in Dorset), all data for the period 4000 BC-AD 43 was provided. CANMORE supplied a broadly equivalent dataset for Orkney and the Outer Hebrides in four separate tranches: information about 'sites', 'sites with notes and events', 'sites with events only' and 'sites highlighted via a free text search' (using the search terms listed in Appx S4 for this last
Taussig, M. 1999. Defacement: Public Secrecy and the Labour of the Negative. Stanford, CA: Stanford University Press

Utriainen, T. 2004. Naked and dressed: Metaphorical perspective to the imaginary and ethical background of the deathbed scene. Mortality 9(2), 132-49

Warren, G. \& Neighbour, T. 2004. Quality quartz: Working stone at a Bronze Age kerbed cairn at Olcote, near Calanais, Isle of Lewis. Norwegian Archaeological Review 37(2), 83-94

Warne, C. 1866. The Celtic Tumuli of Dorset: An account of personal and other researches in the sepulchral mounds of the Durotriges. London: J.R. Smith

Weiner, A. 1992. Inalienable Possessions: The paradox of keeping-while-giving. Berkeley, CA: University of California Press

Whimster, R. 1981. Burial Practices in Iron Age Britain: A discussion and gazetteer of the evidence $c$. 700 B.C.-A.D.43. Oxford: British Archaeological Report 90

White, D. 1981. The Bronze Age Cremation Cemeteries at Simon's Ground, Dorset. Dorchester: Dorset Natural History \& Archaeological Society Monograph 3

Woodward, A. \& Hunter, J. 2015. Ritual in Early Bronze Age Grave Goods: An examination of ritual and dress equipment from Chalcolithic and Early Bronze Age graves in England. Oxford: Oxbow

tranche). Ideally, we would have collected information only on excavated funerary sites or on sites where burial evidence had been recovered/reported by members of the public. In practice, however, HER Event information was recorded only patchily and thus could not be used as a reliable indicator of whether or not a site had been investigated. All the records provided were mapped and uploaded directly into an interim FileMaker Pro database grouped around site-based records for initial refinement (Find, Event, and Source records were attached to Monument records). Each site-based record (eg, a round barrow) was assessed individually, and all of the records associated with sites thought likely to have produced grave goods were transferred to the Grave Goods database.

Within the Grave Goods database, the basic HER information was enhanced using details from published period specific syntheses (eg, Lynch 1970; Henshall 1972; Whimster 1981; Bristow 2001), other published accounts, grey-literature, online sources (eg, the British Museum research database, Pastscape, etc), and unpublished information directly from fieldwork organisations and individual researchers. Site-based information was used to create individual records at 'grave', 'human remains', and 'object' levels. For instance, where a sitebased record existed for an Early Bronze Age round 


\section{A. Cooper et al. COVERING THE DEAD IN LATER PREHISTORIC BRITAIN}

barrow, separate, related records were created for each grave within the round barrow, and then for each body and for each object buried within the grave. Where HER finds records representing individual grave goods existed already, these were retained and enhanced. Where excavated sites which produced grave goods were not represented by an HER or CANMORE records, new site-level records were created. All monument, object, and material terms used in the database were based on SENESCHAL vocabularies (http://www.heritagedata. org/blog/vocabularies-provided/). These terms were either used directly or, where relevant, more specific terms were used and a record was kept of how these mapped onto SENESCHAL terms.

Overall, the analysis provided in this paper is based on information from 1064 excavated funerary sites, which produced 2955 separate graves, human remains relating to at least 3368 dead people (only clearly identified human remains were recorded in separate records - where human remains of a certain type [eg, cremated remains] were noted but not quantified in detail by antiquarian excavators, the MNI of human remains represented was recorded), and 5887 separate grave goods.

\section{RÉSUMÉ}

Couvrir les morts à la préhistoire britannique tardive: Objets insaisissables et technologies puissantes de performance fufnéraire, de Anwen Cooper, Duncan Garrow, Catriona Gibson, et Melanie Giles

Cet article examine le confinement et la couverture de personnes et objets dans les inhumations tout au long de la préhistoire tardive en Grande-Bretagne. De récentes analyses d'assemblages de tombes avec des vestiges organiques exceptionnellement bien conservés ont révélé certains des rôlesparticuliers joués par les couvertures dans les contextes funéraires. Au delà de ces exemples spectaculaires, toutefois, les objets impliqués dans la couverture et le confinement sont en grande partie négligés. Beaucoup de cette 'bande bigarée' de pots et de pierres utilisés pour envelopper,couvrir et contenir corps (et objets) furent ignorés ou détruits par les investigateurs amateurs d'antiquités en quête d'articles plus immédiatement éblouissants. Les récipients et couvercles organiques - sacs, cercueils, linceuls, couvertures - ont rarement été préservés. Notre étude rassemble les divers et souvent insaisissables objets qui ont joué un rôle dans la dissimulation et la protection des inhumations préhistorique, y compris des articles qui contenaient directement corps et objets et ceux qui potentiellement épinglaient les enveloppes organiques (maintenant pour la plupart absentes). Dans l'ensemble, nous soutenons qu'enveloppement, couverture et confinement étaient nettement plus crépandus dans les pratiques funéraires de la préhistoire qu'on ne l'avait reconnu auparavant

\section{ZUSSAMENFASSUNG}

Vom Verhüllen der Toten in der jüngeren Vorgeschichte Großbritanniens: Flüchtige Objekte und starke Technologien funeraler Performanz, von Anwen Cooper, Duncan Garrow, Catriona Gibson, und Melanie Giles

Dieser Beitrag untersucht das Einhüllen und Bedecken von Personen und Objekten in Bestattungen in der jüngeren Vorgeschichte Großbritanniens. Aktuelle Untersuchungen von Beigabenensembles mit außergewöhnlich gut erhaltenen organischen Überresten lassen die speziellen Funktionen erkennen, die Bedeckungen in Bestattungskontexten spielten. Jenseits dieser spektakulären Beispiele jedoch wurden die Objekte, die in das Bedecken und Verhüllen involviert sind, weitgehend übersehen. Viele aus dem übunten Haufen “ aus Gefäßen und Steinen, die benutzt wurden um die Körper (und Objekte) einzuwickeln, zu bedecken und einzufassen waren von antiquarischen Forschern weggeworfen oder zerstört worden bei ihrer Suche nach den offensichtlicher glanzvollen Dingen. Organische Behältnisse und Bedeckungen - Beutel, Särge, Totenhemden, Decken - blieben selten erhalten. Unsere Untersuchung versammelt diese vielfältigen und oft flüchtigen Objekte, die beim Bedecken und Einhüllen von prähistorischen Bestattungen eine Rolle spielten, einschließlich von Dingen, die unmittelbar Körper und Objekte umschlossen, und solchen, die möglicherweise organische Hüllen (heute meist verschwunden) zusammenhielten. Zusammenfassend halten wir fest, dass Einwickeln, Bedecken und Einhüllen ein weitaus gängigerer Bestandteil prähistorischer funeraler Praktiken waren als bislang erkannt. 


\section{RESUMEN}

Afrontando la muerte durante la Prehistoria Reciente en Gran Bretaña: objetos imprecisos y tecnologías de prestigio en el ámbito funerario, por Anwen Cooper, Duncan Garrow, Catriona Gibson, y Melanie Giles Este artículo examina el contenido y la cubrición de los cuerpos y objetos documentados en enterramientos de la Prehistoria Reciente en Gran Bretaña. Los recientes análisis de los conjuntos funerarios con restos orgánicos excepcionalmente conservados han revelado algunas de las funciones desempeñadas por las cubiertas en los contextos funerarios. Más allá de los ejemplos espectaculares, sin embargo, los objetos implicados en la cubrición y contención de los enterramientos han sido ignorados. Muchos de los abigarrados conjuntos de cerámicas y objetos líticos empleados para envolver, cubrir y contener los cuerpos (y los objetos) fueron descartados o destruidos por anticuaristas en su búsqueda de objetos más deslumbrantes. Los contenedores y cubiertas orgánicas - bolsas, ataúdes, protectores y mantas - rara vez se conservan. Nuestro estudio presenta los diversos y, a menudo esquivos, objetos que tuvieron un importante papel en la cubrición y contención de los enterramientos prehistóricos, incluyendo elementos que encerraban los cuerpos y los objetos directamente, y aquéllos que potencialmente fijaban (actualmente en su mayoría ausentes) envoltorios orgánicos. En general, sostenemos que el envoltorio, la cubrición y la contención fueron prácticas funerarias prehistóricas más relevantes de lo que previamente se ha reconocido. 